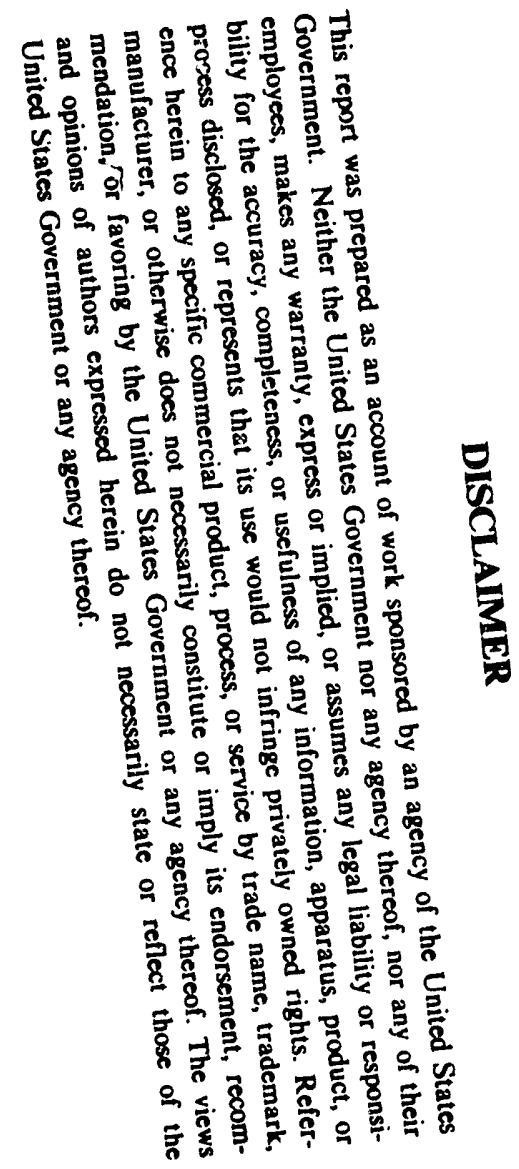

Submitted to

DOE Nevada Operations Office

U.S. Department of Energy

March 1993

\section{GROUNDWATER CHEMISTRY \\ AT THE NEVADA TEST SITE:
Data and Preliminary Interpretations \\ AT THE NEVADA TEST SITE:
Data and Preliminary Interpretations \\ RECEIVED JUL 191993 \\ OSTI}

\author{
Prepared by \\ Jenny B. Chapman and Brad F. Lyles
}

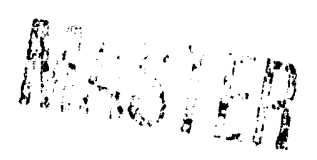

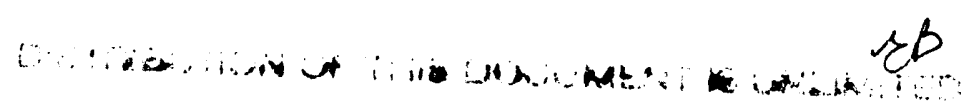


This report was prepared as an account of work sponsored by the United States Government. Neither the United States nor the United States Department of Energy, nor any of their employees, makes any warranty, express or implied, or assumes any legal liability or responsibility for the accuracy, completeness or usefulness of any information, apparatus, product or process disclosed, or represents that its use would not infringe privately owned rights. Reference herein to any specific commercial product, process, or service by trade name, mark, manufacturer, or otherwise, does not necessarily constitute or imply its endorsement, recommendation, or favoring by the United States Government or any agency thereof. The views and opinions of authors expressed herein do not necessarily state or reflect those of the United States Government or any agency thereof.

This report has been reproduced directly from the best available copy.

Available to DOE and DOE contractors from the Office of Scientific and Technical Information, P.O. Box 62, Oak Ridge, TN 37831; prices available from (615) 576-8401.

Available to the public from the National Technical Information Service, U.S. Department of Commerce, 5285 Port Royal Rd., Springfield, VA 22161. 


\title{
GROUNDWATER CHEMISTRY AT THE NEVADA TEST SITE: Data and Preliminary Interpretations
}

\author{
by \\ Water Resources Center \\ Desert Research Institute \\ University and Community College System of Nevada \\ prepared for \\ DOE Nevada Operations Office \\ U.S. Department of Energy \\ Las Vegas, Nevada
}

Publication No. 45100

March 1993

The work upon which this report is based was supported by the U.S. Department of Energy under Contract \#DE-AC08-90NV10845. 


\section{CONTENTS}

ABSTRACT $\ldots \ldots \ldots \ldots \ldots \ldots \ldots \ldots \ldots \ldots \ldots \ldots \ldots \ldots \ldots \ldots \ldots \ldots \ldots \ldots$

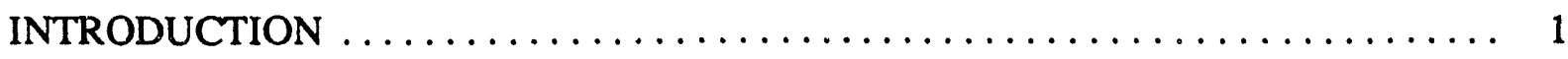

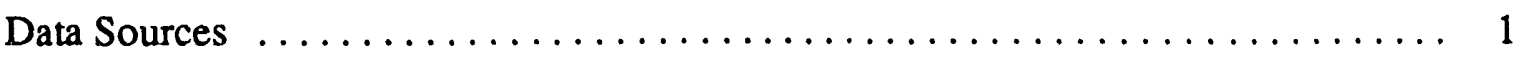

COMPARISON BETWEEN 1957-1977 DATA AND 1984-1990 DATA . . . . . . . . 2

AREAL DISTRIBUTION OF DISSOLVED IONS IN GROUNDWATER $\ldots \ldots \ldots \ldots 11$

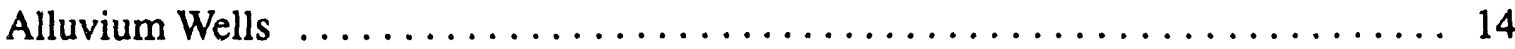

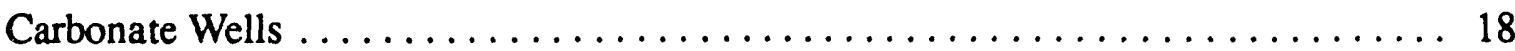

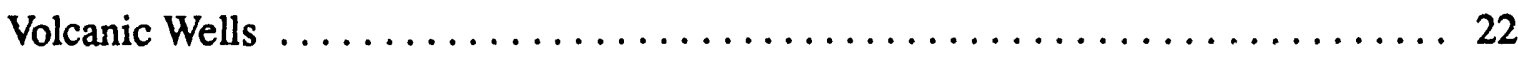

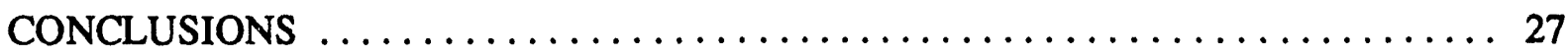

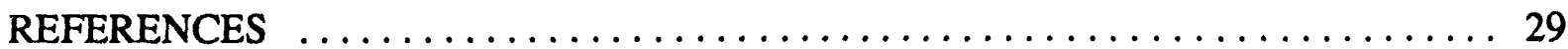

\section{APPENDIX A}

Water chemistry data from samples collected between 1957 and 1977 from wells

\section{APPENDIX B}

Water chemistry data from samples collected between 1984 and 1990 from wells at and near the NTS.

\section{APPENDIX C}

Combined chemical dataset of samples collected from 1957 to 1990, with averages calculated for locations where multiple samples have been collected.

\section{FIGURES}

1. Location of the Nevada Test Site in southern Nevada and wells with chemical analyses reported in this study

2. Trilinear diagram showing relative ion percentages for samples collected from UE-15d Water Well ...................................... 5

3. Trilinear diagram showing relative ion percentages for samples collected from well UE-16f Eleana . . . . . . . . . . . . . . . . . . . . . . . . . . . . . . 6

4. Trilinear diagram showing relative ion percentages for samples collected from well UE-16d Eleana

5. Trilinear diagram showing relative ion percentages for samples collected from well Army

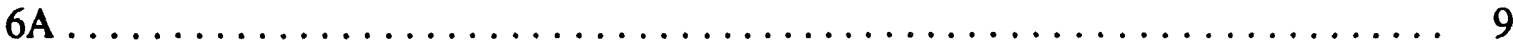

6. Trilinear diagram showing relative ion percentages for samples collected from USGS Test Well D 
7. Trilinear diagram showing relative ion percentages for samples collected from

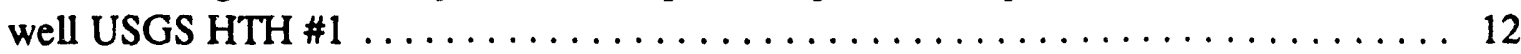

8. Trilinear diagram showing relative ion percentages for samples collected from all wells reported in this study, differentiated based on aquifer rock type $\ldots \ldots \ldots 13$

9. General groundwater flow directions in the NTS area $\ldots \ldots \ldots \ldots \ldots \ldots \ldots$

10. Wells completed in alluvial materials at and near the NTS for which water

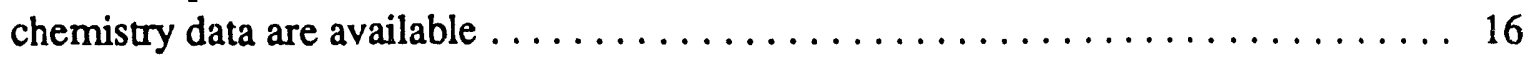

11. Areal variation in water chemistry for wells completed in alluvial materials, as

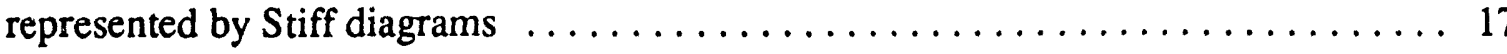

12. Wells and springs completed in carbonate rocks (or similar formations) at and near the NTS for which water chemistry data are available $\ldots \ldots \ldots \ldots \ldots \ldots . \ldots 19$

13. Areal variation in water chemistry for wells and springs completed in carbonate rocks (or similar formations), as represented by Stiff diagrams

14. Wells completed in volcanic rocks at and near the NTS for which water chemistry

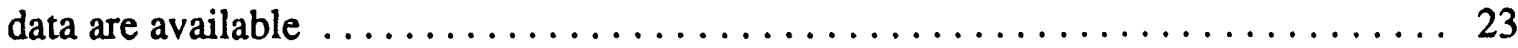

15. Wells completed in volcanic rocks on Pahute Mesa for which water chemistry data are available

16. Areal variation in water chemistry for wells completed in volcanic rocks, as represented by Stiff diagrams

17. Areal variation in water chemistry for wells completed in volcanic rocks on Pahute Mesa, as represented by Stiff diagrams

18. Trilinear diagram showing relative ion percentages for samples collected from volcanic aquifers on Pah'te Mesa .

\section{TABLES}

1. Dissolved ion concentrations in $\mathrm{mg} / \mathrm{L}$ for wells in three areas of the carbonate aquifer and calculated mass percentages needed to create water at $A$ rmy \#1 Water Well from the other two types. 


\begin{abstract}
The interpretation of chemical analyses of groundwater collected at and near the Nevada Test Site (NTS) has been vital in developing conceptual models of groundwater flow in the area. These conceptual models are tested using recent chemical data generated by the Desert Research Institute, as well as historic analyses from the U.S. Geological Survey. A total of 81 wells are represented by analyses from 1957 to 1990 , with generally excellent agreement between repeat samples from the same location. As identified by previous workers, three hydrochemical facies are represented by the samples: $\mathrm{Ca}-\mathrm{Mg}-\mathrm{HCO}_{3}$ water in carbonate rocks or alluvium derived from carbonates, $\mathrm{Na}-\mathrm{K}-\mathrm{HCO}_{3}$ water in volcanic rocks and alluvium derived from volcanic rocks, and a mixed facies found in many carbonate and alluvium water samples, and some volcanic waters. There is a general lack of lateral continuity in chemical characteristics along presumed flowpaths within each hydrologic unit (alluvium, carbonate, and volcanic). Though a lack of continuity between basins on the east side of the NTS was expected for water in alluvial and volcanic units due to the absence of interbasin flow, chemical differences observed within individual basins suggest a dominance of vertical over lateral flow. Groundwater in volcanic materials on the east side of Yucca and Frenchman Flats and on the west side of Pahute Mesa and Yucca Mountain has a nearly pure $\mathrm{Na}-\mathrm{K}-\mathrm{HCO}_{3}$ signature that reflects contact with primarily volcanic material. Groundwater in volcanic units in the middle of the NTS and on the east side of Pahute Mesa contains a higher proportion of $\mathrm{Ca}, \mathrm{Mg}, \mathrm{Cl}$, and $\mathrm{SO}_{4}$ than the other volcanic waters and indicates the contribution of water from the upper carbonate aquifer and/or hydrothermally altered regions. The lack of lateral chemical continuity in volcanic water on Pahute Mesa is attributed to stratigraphic and structural complexities in the volcanic units of the caldera complex. Areal variations in conservative ions in the carbonate aquifer indicate that though the lower carbonate aquifer may be considered a single hydraulic unit in gross flow terms, it may be considerably more complex when evaluating solute transport. Striking differences between groundwater in carbonate units at the south end of Yucca Flat and groundwater upgradient indicate the contribution of water from volcanic units, either by downward leakage or by lateral flow from structurally juxtaposed formations. A similar contribution of groundwater from volcanic formations is indicated by sodium and chloride concentrations in the carbonate aquifer near Fortymile Wash. The reduction in dissolved solutes in the carbonate aquifer at the southeast end of the NTS, as compared to water sampled at the south end of Yucca Flat, suggests a major contribution of groundwater flow coming from east of the NTS.
\end{abstract}




\section{INTRODUCTION}

The dissolved ionic constituents of groundwater are a record of the minerals the water has contacted (either dissolving or precipitating) as it moves through soil and rock. As such, the chemistry of the water can be used to trace groundwater movement. The chemistry of groundwater in the Nevada Test Site (NTS) area has been instrumental in the development of the most basic flow hypotheses for the region. For example, the movement of water from volcanic aquifers into the regional carbonate aquifer in the vicinity of the NTS was deduced in large part by an increase in sodium concentration in the carbonate groundwater sampled at and downgradient from the NTS (Schoff and Moore, 1964). Low sodium concentrations in groundwater from the carbonate aquifer in the vicinity of Indian Springs were used as evidence that a groundwater divide directs flow from the NTS toward Ash Meadows rather than Las Vegas. Recognizing the importance of groundwater chemistry to hydrogeologic interpretations, the U.S. Geological Survey (USGS) performed extensive sampling in the NTS region that culminated with publications by Blankennagel and Weir in 1973 and Winograd and Thordarson in 1975. Three hydrochemical facies in and near the NTS were recognized: a $\mathrm{Ca}-\mathrm{Mg}-\mathrm{HCO}_{3}$ facies from groundwater in carbonate rocks east and south of the NTS, a $\mathrm{Na}-\mathrm{K}-\mathrm{HCO}_{3}$ facies from groundwater in volcanic rocks, and a $\mathrm{Ca}-\mathrm{Mg}-\mathrm{Na}-\mathrm{HCO}_{3}$ (mixed facies) in carbonate rocks beneath the NTS and in the east-central Amargosa Desert and Ash Meadows areas (Schoff and Moore, 1964).

The chemical data from which so many important conclusions were drawn are scattered through a number of USGS publications, and a few are referenced as personal communications or data on file in Denver USGS offices. Most of these data were obtained from samples collected in the late 1950s and early 1960s, though a few new wells were drilled and sampled in the late 1970s. The late 1980s and early 1990s have seen a resurgence of water sampling on the NTS, with samples collected from pre-existing wells and 28 new wells. These samples have been collected and analyzed by the Desert Research Institute (DRI).

This document compiles the USGS and DRI analyses in an effort to present a reasonably complete dataset for groundwater chemistry at the NTS. No exhaustive effort was made to identify all historic data; rather, the focus was on compiling the bulk of the analyses used to formulate important ideas about groundwater flow at the NTS. Some data, particularly recent samples from the Yucca Mountain area, have no doubt been overlooked. In cases where both old (1957-1977) and new (1983-1990) samples were available for the same well, the analyses have been compared using trilinear diagrams of ion percentages. In most cases, analyses compared well, so the datasets were combined and mean values for the constituents and $\mathrm{pH}$ for a given well were calculated. By dividing the wells into three groups based on the reported lithology of the sampling horizon (alluvium, volcanic, carbonate), the areal distribution of ions was mapped and compared to general groundwater flow directions.

\section{Data Sources}

Chemical data for the period 1957 to 1977 were gathered from the following USGS reports: Schoff and Moore (1964), Blankennagel and Weir (1973), Young (1965), Thordarson et al. (1962), 
Robinson and Beetem (1965), and Dinwiddie and Weir (1979). These data are presented in Appendix A. Well names used in the appendices and throughout the text of this report are consistent with the names used in the 1991 edition of the Raytheon Services Nevada "NTS Drilling and Mining Summary." Wells are reported in the appendices in order of increasing Nevada state north coordinate.

All analyses but one reported from the period 1983 to 1990 were performed by the Water Analysis Laboratory of the Desert Research Institute. The one exception is the analysis from UE-25p \#1, performed by the USGS and reported by Benson and McKinley (1985). Some of these DRI analyses have appeared previously in specific project reports prepared by DRI for the Department of Energy. These data are presented in Appendix B. Together, the USGS and DRI analyses represent 81 wells at and near the NTS (Figure 1). Average ion and pH values computed by combining the 1957-1977 and 1983-1990 datasets are given in Appendix C.

The chemical analyses reported in the appendices were performed on samples collected in several different ways. Samples were either collected during drilling and well development, with permanent pumps installed in supply wells, with temporary pumps used for aquifer testing and sampling, or with bailers. The degree to which a sample is representative of formation water varies with each method, but also varies with how a method was applied (e.g., number of pumping volumes before sampling) and sample collection and preservation procedures (e.g., filtering and acidifying cation samples). No attempt was made to assign quality ratings to the analyses assembled for this report because detailed sampling information was rarely available. However, it may aid the reader to keep in mind the following generalizations. Many of the analyses reported in Appendix A and the 1988 analyses from Pahute Mesa \#3 in Appendix B were collected during drilling and well development and the resulting analyses could be influenced by residual drilling fluids. In some cases, this means that the producing horizon is actually different from sample to sample (e.g., samples were collected from multiple formations in UE-16d Eleana, USGS HTH \#1, and U-19d \#2). In Appendix B, samples from NTS supply wells were collected by pumping, and due to the lengthy pumping history of these wells, these samples are the most likely to be representative of formation water. These supply wells are those with "Water Well" in the name, plus UE-16d Eleana. Wells located around Yucca Mountain (wells with a "WT" for water table in the name) were sampled with a low volume piston pump and collected after $\mathrm{pH}$, temperature, and electrical conductivity had stabilized (Matuska, 1989). The other samples in Appendix B were collected with a discrete bailer. The bailer was evacuated at the surface, lowered to a depth corresponding to a screened or open interval, then a valve was opened for sample collection. Because the water collected was present in the well bore, not the formation, there is the possibility that degassing of $\mathrm{CO}_{2}$ could have occurred and altered the $\mathrm{pH}$ and ion concentrations, and that reactions with casing materials could have occurred.

\section{COMPARISON BETWEEN 1957-1977 DATA AND 1984-1990 DATA}

Eighteen wells have chemical analyses available from both the earlier and later sampling periods. Of these 18,12 have no major change in salinity and relative ion percentages between the 


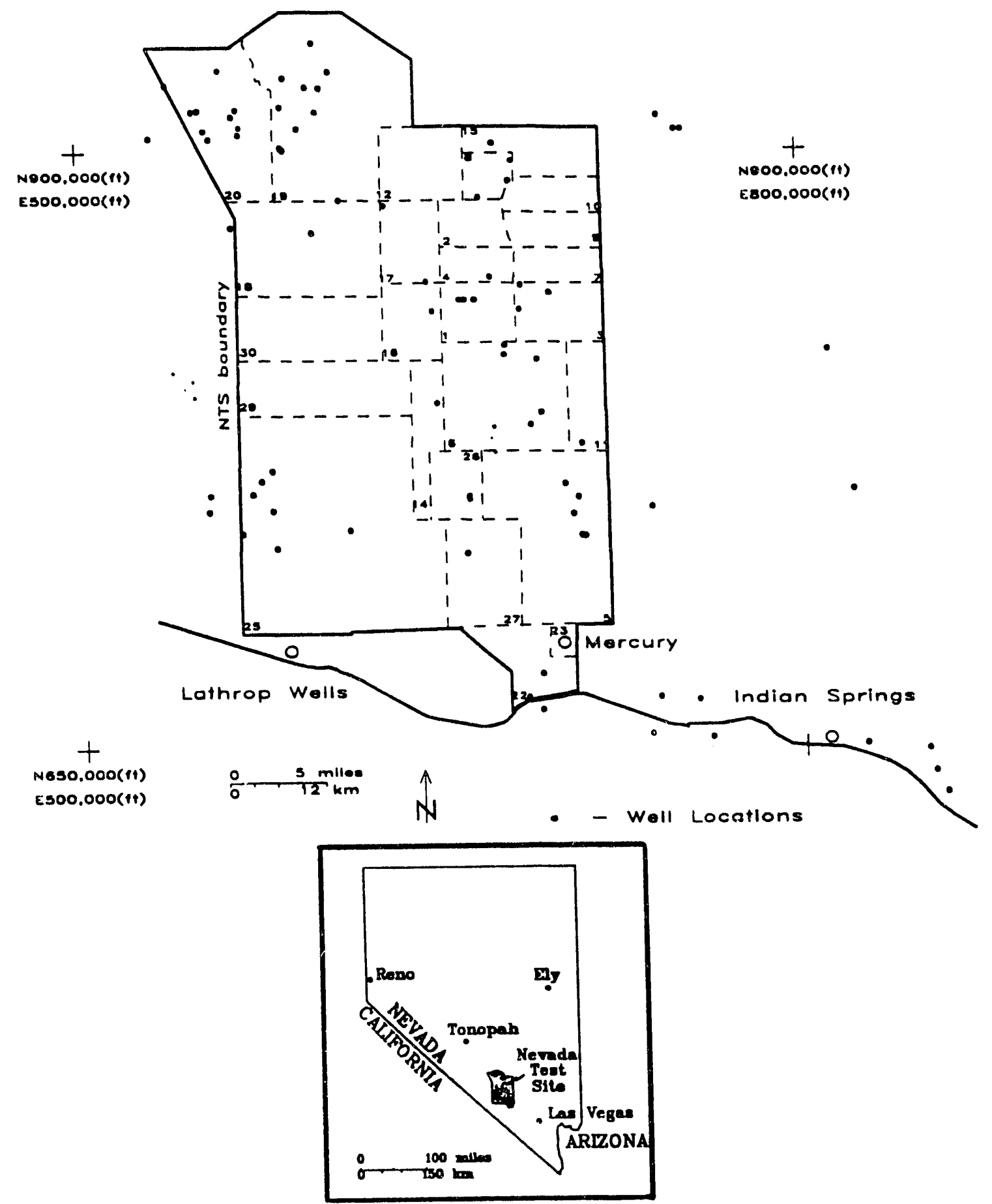

Figure 1. Location of the Nevada Test Site and wells with chemical analyses reported in this study. Well names can be found on detailed maps later in the report. 
two groups. In a few cases (e.g., Water Well 2), there is no obvious break between the 1957-1977 and 1984-1990 data groups but there is a relatively large spread in the ion ratios of the earlier analyses. This may be caused by continuing well development with pumping, resulting in more representative formation water with time. The six wells with significant differences between the old and new analyses are discussed below in the following order: UE-15d Water Well, UE-16f Eleana, UE-16d Eleana, Army 6A, USGS Test Well D, and USGS HTH \#1. Because there is little change in overall salinity of samples from a given well, trilinear plots are used to discuss temporal changes in measured chemical composition. On the plots, the water composition is represented as percentages of the total milliequivalents per liter of cations (left triangle), percentages of the total milliequivalents per liter of anions (right triangle), and a combined representation of the anions and cations by projecting these points onto a central diamond.

A sample collected from UE-15d Water Well in 1989 is within $10 \%$ of the ion ratios of samples collected in 1961 and 1962 (Figure 2). However, two samples collected in 1990 have shifted to approximately 15 to $20 \%$ more calcium relative to other cations, as compared to the earlier samples. Total salinity is essentially unchanged. It seems unlikely that preservation or analytical errors could be the source of the difference because there are two independent samples defining each group, and anion percentages remain stable. Rather, the difference may be related to a reduction in pumping at the well that began in 1990 and culminated with the pump becoming inoperative in 1991 . This well is completed in fractured quartzite with a dolomite unit at the bottom of the hole. The 1960's and 1989 samples probably reflect water produced primarily from the quartzite. The change in chemistry in 1990 could reflect mixing of water from the dolomite in the well bore in the long periods between pumping in 1990. The shift in chemical composition is important because there has been an increase in the tritium concentration in this well over the last 15 years (Lyles, 1990 and 1992). Identifying the formations contributing water to the well would aid in determining the source of the tritium. To this end, the inoperative pump in UE-15d Water Well should be pulled and hydrologic logging performed.

Analyses are available from UE-16f Eleana from samples collected at the time of drilling and testing (1977) and in 1988. The three samples show a progressive increase in the amount of $\mathrm{HCO}_{3}$ relative to the other anions, with the 1988 sample having greater than $95 \% \mathrm{HCO}_{3}$, less than $5 \% \mathrm{Cl}$, and essentially no $\mathrm{SO}_{4}$ (Figure 3 ). This trend could be the result of well development, meaning that the most recent sample is the most representative of formation water.

The three 1977 samples from UE-16d Eleana were collected during drilling and show up to $10 \%$ shifts in ion percentages from one sample to another (Figure 4). Presumably, these variations are related to different contributing horizons at the time of sampling. The 1977 sample most different from the 1990 sample was collected on 6-19-77 and is recorded as being from the Eleana Formation (quartzite). The well was recompleted in 1981 with the Eleana Formation cemented off and perforations installed across the Tippipah Limestone, so it is not surprising that there are differences between the 6-19-77 sample and the one in 1990. The greatest similarity in cations exists between the 1990 sample and the one collected on 6-14-77. The 6-14 sample was the only earlier sample 

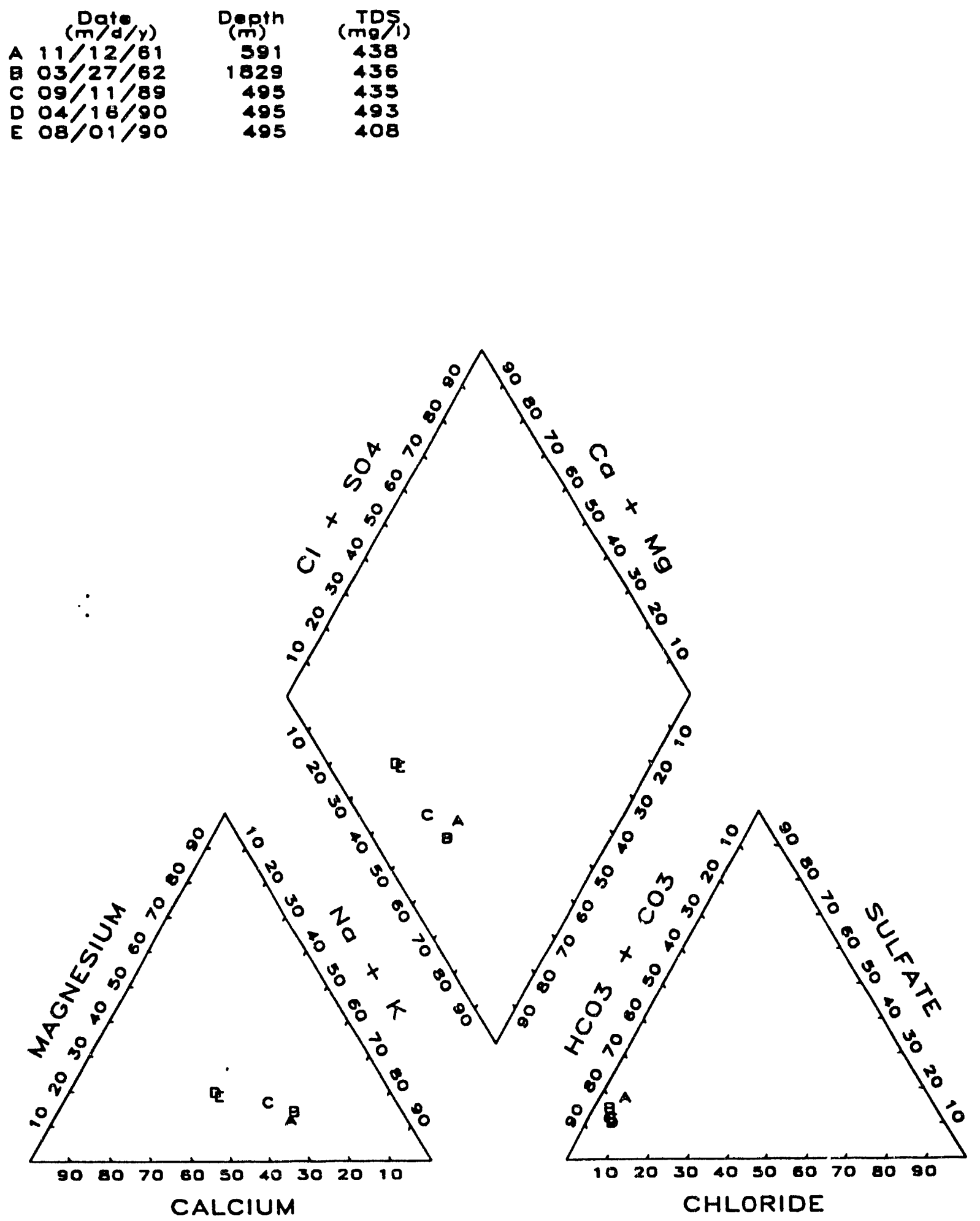

Figure 2. Trilinear diagram showing relative ion percentages for samples collected from UE-15d Water Well. The depth of the 1989 and 1990 samples is the location of the pump. The well was open to $1829 \mathrm{~m}$. 

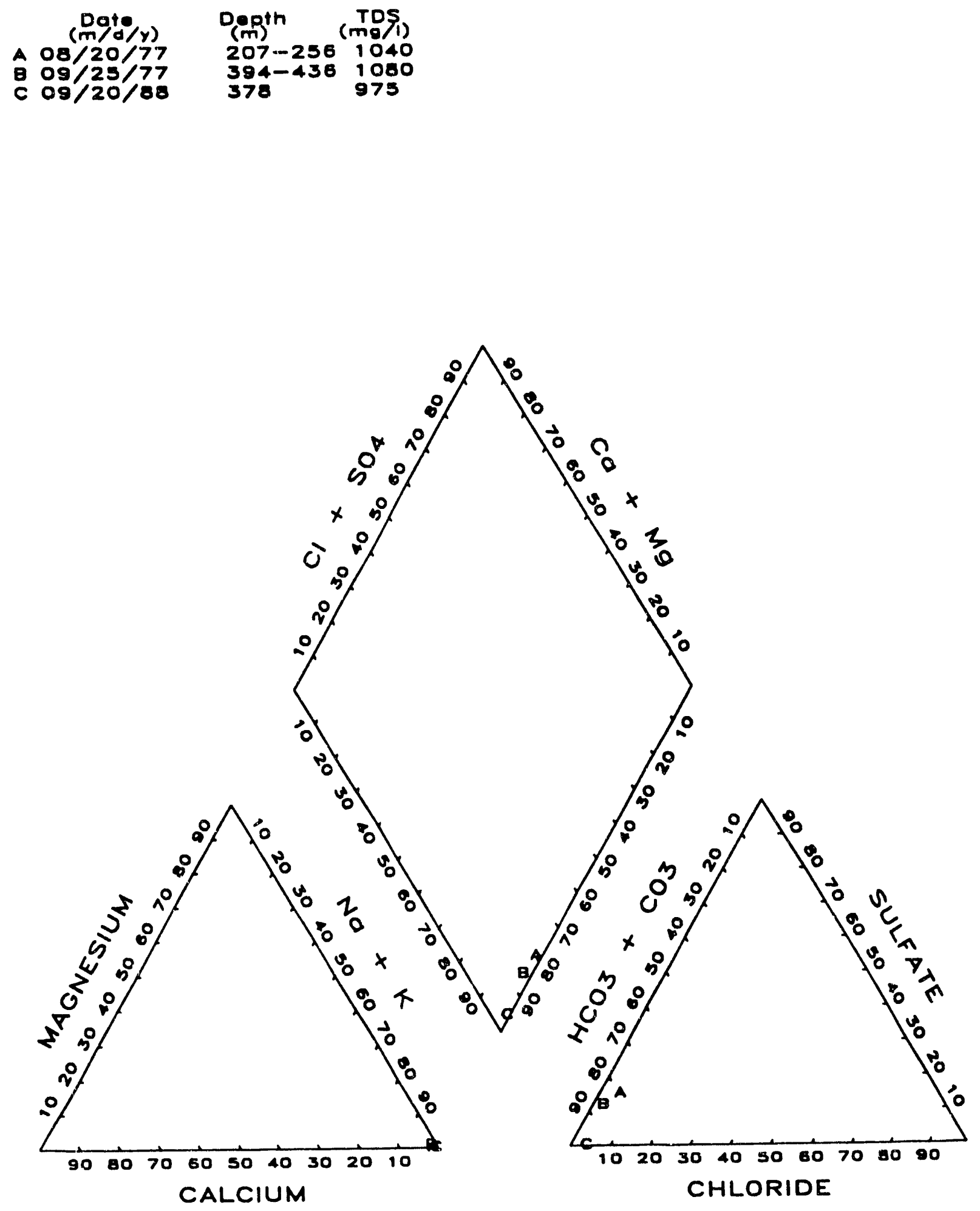

Figure 3. Trilinear diagram showing relative ion percentages for samples collected from well UE-16f Eleana. 

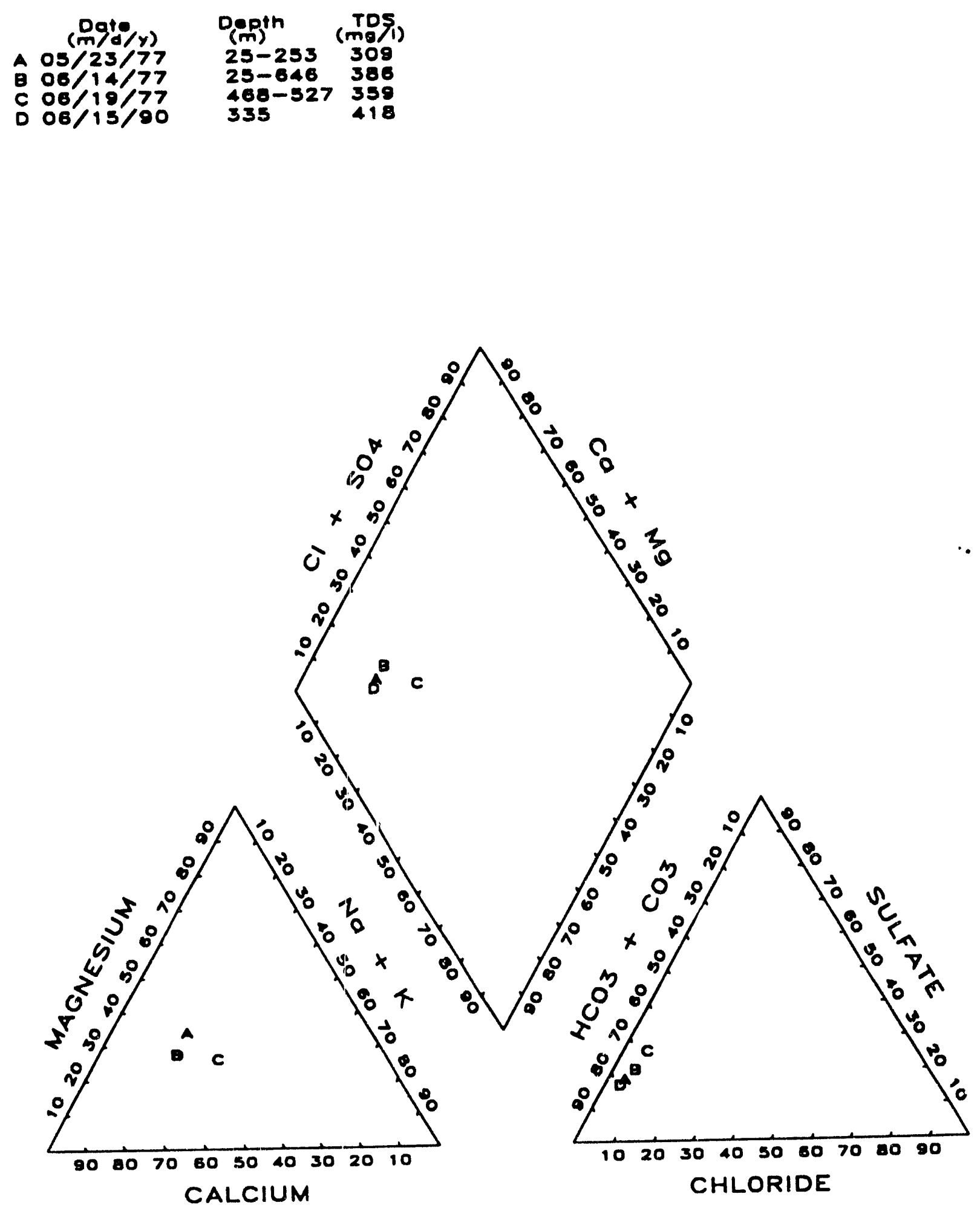

Figure 4. Trilinear diagram showing relative ion percentages for samples collected from well UE-16d Eleana. 
that was collected by pumping, and the similarity in chemistries suggests that the Tippipah Limestone was probably the major contributing zone to the borehole during pumping in 1977 .

The 1958 analysis of water from well Army 6A differs drastically from two analyses of samples collected in 1986 (Figure 5). The total dissolved solids (TDS) concentration in the more recent samples is about 7\% lower than the earlier one, but the major difference is a large increase in the amount of magnesium at the expense of sodium, and an increase in $\mathrm{SO}_{4}$ at the expense of $\mathrm{HCO}_{3}$. Schoff and Moore (1964) were suspicious of the 1958 analysis because it yielded a $\mathrm{Na}-\mathrm{K}$ water in an area where, other water was a $\mathrm{Ca}-\mathrm{Mg}$ type. The later analyses do not resolve the problem, but instead make it one of a $\mathrm{Mg}-\mathrm{SO}_{4}$ type water in a $\mathrm{Ca}-\mathrm{Mg}-\mathrm{HCO}_{3}$ area. Schoff and $\mathrm{Moore}$ concluded that the earlier analysis did not represent formation water and suggested that it could have been contaminated by cement used in the well during completion. However, the measured $\mathrm{pH}(8.0)$ was much lower than what would be expected from a cement-contaminated water (greater than 11). The later analyses also have reasonable $\mathrm{pH}$ values (around 8.6), and cation/anion charge balances are very good for both the 1958 and later analyses.

Though cement contamination seems unlikely, water introduced during drilling could have altered the in situ chemistry. Given that the well has a low production rate (1 to $2 \mathrm{gpm}$ ) and was abandoned immediately, water introduced during drilling in 1955 may not have been purged by the time the sample was collected in 1958. The difference between the 1958 and 1986 analyses may indicate that diffusive and/or advective flow have equilibrated the well with its surroundings. The $\log$ of well Army 6A includes quartzite and limestone, but only quartzite and siltstone are intersected by the perforated interval (Moore, 1962). Both the old and new analyses indicate equilibrium with dolomite, and some source of sulfate is needed, neither of which are consistent with a quartzite aquifer. Though anomalous, there are other wells with unusual chemistries in the area (USGS HTH "F" and Army 6) that have been attributed to hydrothermal activity and/or as yet undetected evaporite deposits in the subsurface. Pumping the well at a low flow rate, monitoring field parameters, then sampling after purging many well volumes could reduce the uncertainty about the chemistry of this well.

Samples collected in 1986 from USGS Test Well D are substantially lower in TDS than the one collected in 1961. This difference in TDS is not reflected in any change in cation ratios (Figure 6), but a shift to a higher proportion of $\mathrm{HCO}_{3}$ in the 1986 samples is due to lower $\mathrm{Cl}$ and sulfate concentrations in those samples as compared to the 1961 sample. The 1960 sample was collected from a bailer after three hours of nearly continuous bailing had removed 12,000 liters ( 3100 gallons) from the well (Thordarson et al., 1962). Though care was taken to minimize contamination of groundwater by using a cable-tool rig and not introducing bentonite or chemical additives in the zone of saturation, the aquifer was penetrated by at least 16 meters $(53 \mathrm{ft}$ ) and water was injected in the hole for cuttings removal, before groundwater was recognized. The hole also experienced serious caving problems both from the overlying tuff units when the hole penetrated the carbonates (with blocks of tuff falling into the bailer), and from interbedded siltstone and argillite formations. Fine material from these horizons may have dissolved into the well water and added to the TDS concentration. Though no extensive well development or pumping is known to have occurred at 

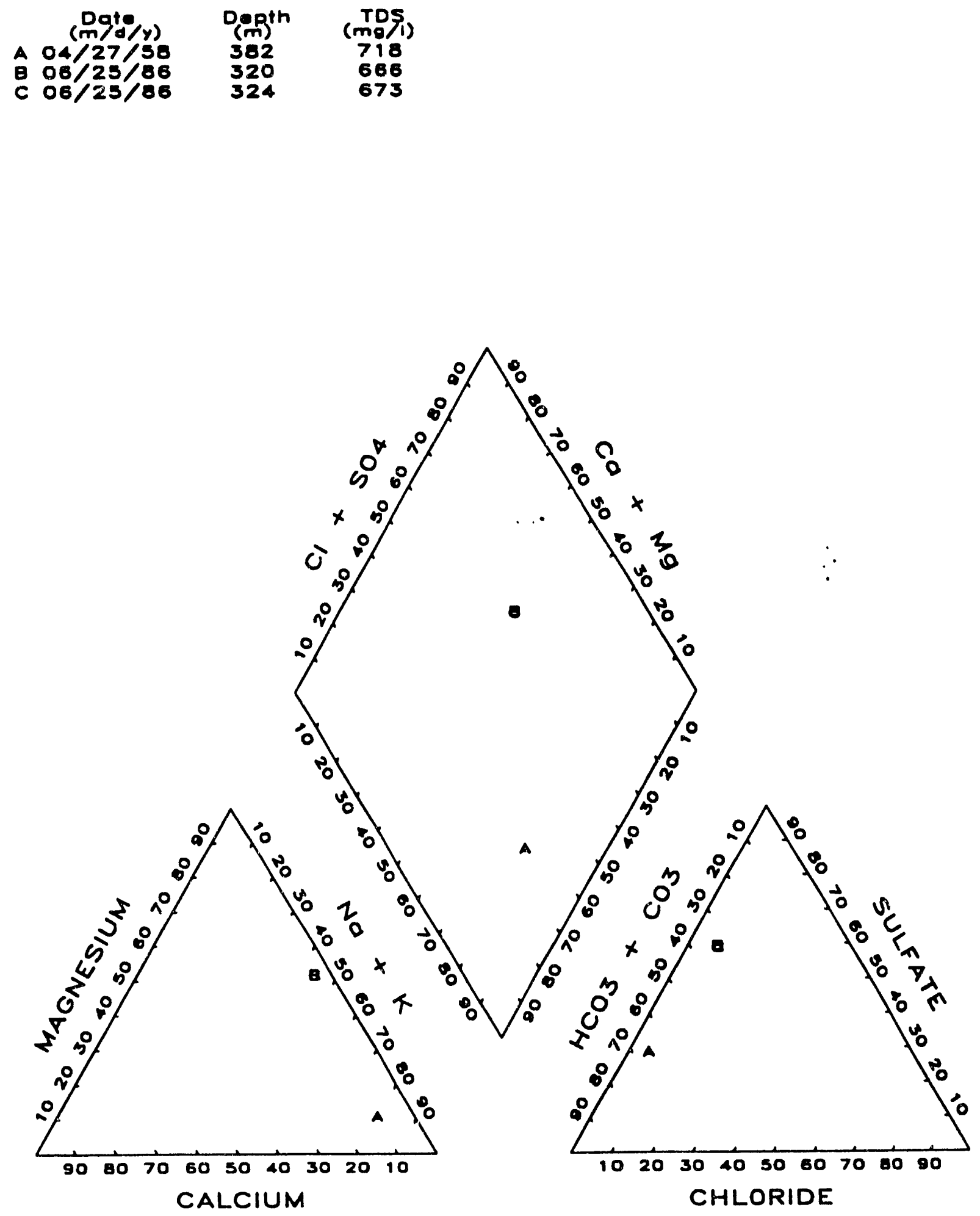

Figure 5. Trilinear diagram showing relative ion percentages for samples collected from well Army 6A. 

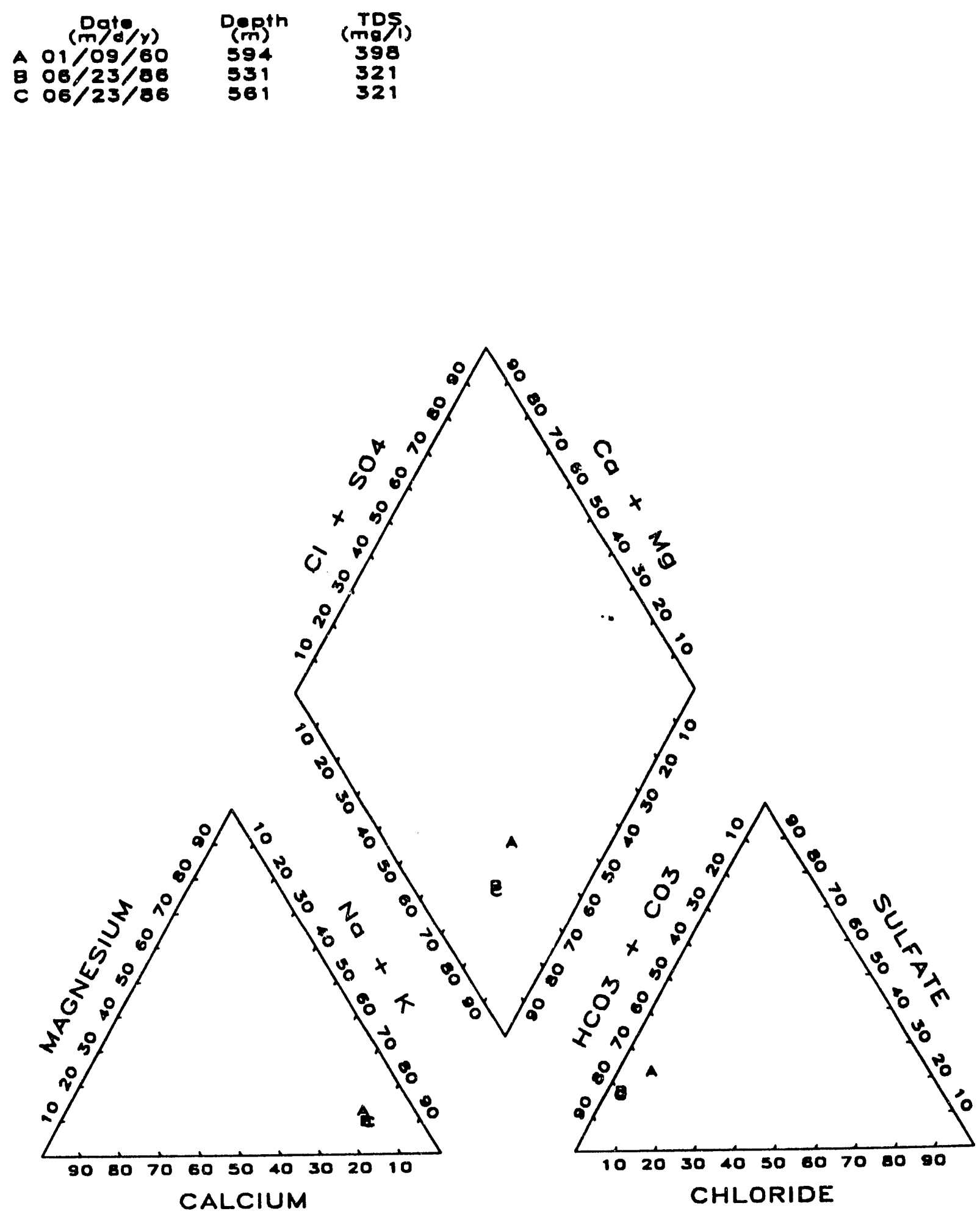

Figure 6. Trilinear diagram showing relative ion percentages for samples collected from USGS Test Well D. 
USGS Test Well D between 1961 and 1986, equilibration of well water with the carbonate aquifer by advective or diffusive flow is reasonable over this time scale. Though the ionic composition of the 1986 samples may be more representative of formation water, the lower $\mathrm{pH}$ of the 1961 sample may be closer to in situ conditions. The 1986 samples were collected with a discrete bailer without previous purging of wellbore water, so some degassing of $\mathrm{CO}_{2}$ and elevation of $\mathrm{pH}$ could have occuried. As with Army 6A, new samples from this well should be collected after pumping and monitoring field parameters.

Some of the variation observed at well USGS HTH \#1 (Figure 7) comes from sampling from two discrete aquifers. Samples from the underlying carbonate aquifer were only collected in 1961 and 1962. These are the samples with the highest calcium percentages. The other samples collected in 1960 and from 1986-1990 were collected from volcanic zones and show higher proportions of sodium and bicarbonate, with the 1986-1990 set clustering more in the $\mathrm{Na}$ and $\mathrm{HCO}_{3}$ apexes. All of the samples together appear to form a mixing line between a higher salinity, carbonate-influenced water and a lower salinity, volcanic-influenced water. This suggests that differences between individual samples relate to their collection position in the borehole rather than any hydrochemical changes with time. Flow relationships between the five perforated intervals in USGS HTH \#1 and how they relate to the 1986-1990 samples are discussed by Lyles et al. (1991).

\section{AREAL DISTRIBUTION OF DISSOLVED IONS IN GROUNDWATER}

The three hydrochemical facies identified by previous workers are also represented in the averaged dataset created by combining the 1957-1977 data with the 1984-1990 data. Groundwater ranges from a $\mathrm{Ca}-\mathrm{Mg}-\mathrm{HCO}_{3}$ water to a $\mathrm{Na}-\mathrm{K}-\mathrm{HCO}_{3}$ water, with a rough mixing line between the two on the cation triangle (Figure 8). Water from volcanic rocks predominates in the $\mathrm{Na}-\mathrm{K}$ area, while water from the carbonate rocks has generally higher percentages of calcium and magnesium. Most waters from carbonate rocks have a mixed chemical character, as do some volcanic aquifer waters. Water from alluvial deposits spans the chemical spectrum, depending on the source rock for the alluvial material. With the exception of a few outliers, there is less variation in anion percentages, with most waters dominated by bicarbonate.

The chemistry of the combined dataset continues to strongly support the hypothesis of Schoff and Moore (1964) and others that two distinct types of water develop depending on whether groundwater moves through a volcanic or carbonate aquifer. Significantly, the mixed nature of many samples from the NTS area indicates a water that has moved through both types of material.

Given the importance of aquifer material on groundwater chemistry, the combined 1957-1990 dataset was subdivided into three groups: wells completed in alluvium (14 wells), wells completed in carbonate rocks (17 wells), and wells completed in volcanic rocks (50 wells). This simplistic designation, while easy to make in many cases, was more problematic in others. An example is UE-16f Eleana, which is completed in the Eleana Formation, comprised of siltstone, sandstone, and quartzite with minor limestone. This well was grouped with the carbonates because the lithology seemed to have more in common with that group than with the volcanics or alluvium. However, it 


\begin{tabular}{|c|c|c|c|c|c|}
\hline 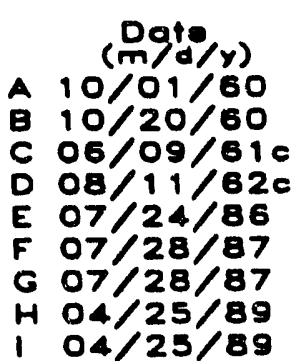 & $\begin{array}{l}\text { Depth } \\
(17)^{\text {th }} \\
171 \\
337 \\
1137 \\
1282 \\
1281 \\
461 \\
725 \\
1119 \\
588 \\
622\end{array}$ & $\begin{array}{l}\text { (TDS } \\
\text { (mog) } \\
151 \\
130 \\
278 \\
208 \\
141 \\
129 \\
115 \\
125 \\
128\end{array}$ & 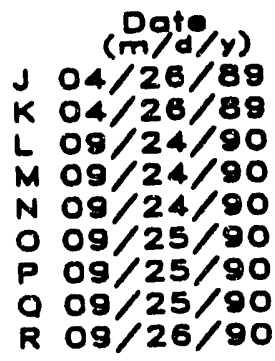 & $\begin{array}{l}\text { Depth } \\
651 \\
681 \\
686 \\
472 \\
588 \\
622 \\
649 \\
686 \\
732 \\
1122\end{array}$ & 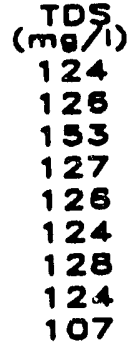 \\
\hline
\end{tabular}

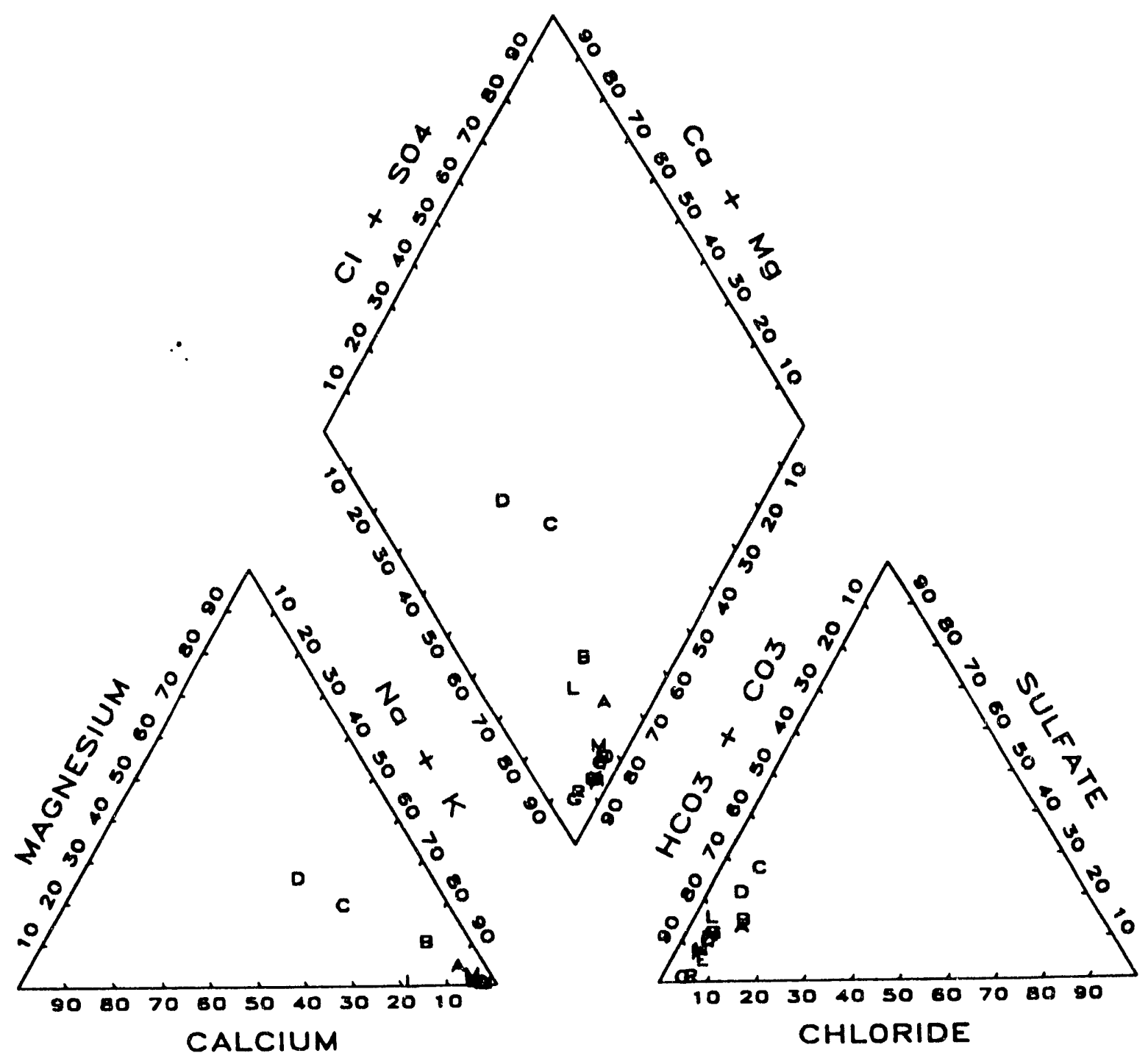

Figure 7. Trilinear diagram showing relative ion percentages for samples collected from well USGS HTH \#1. Samples C and D (with a "c" after the date) were collected from carbonate rocks, while all of the others were from volcanic units. 


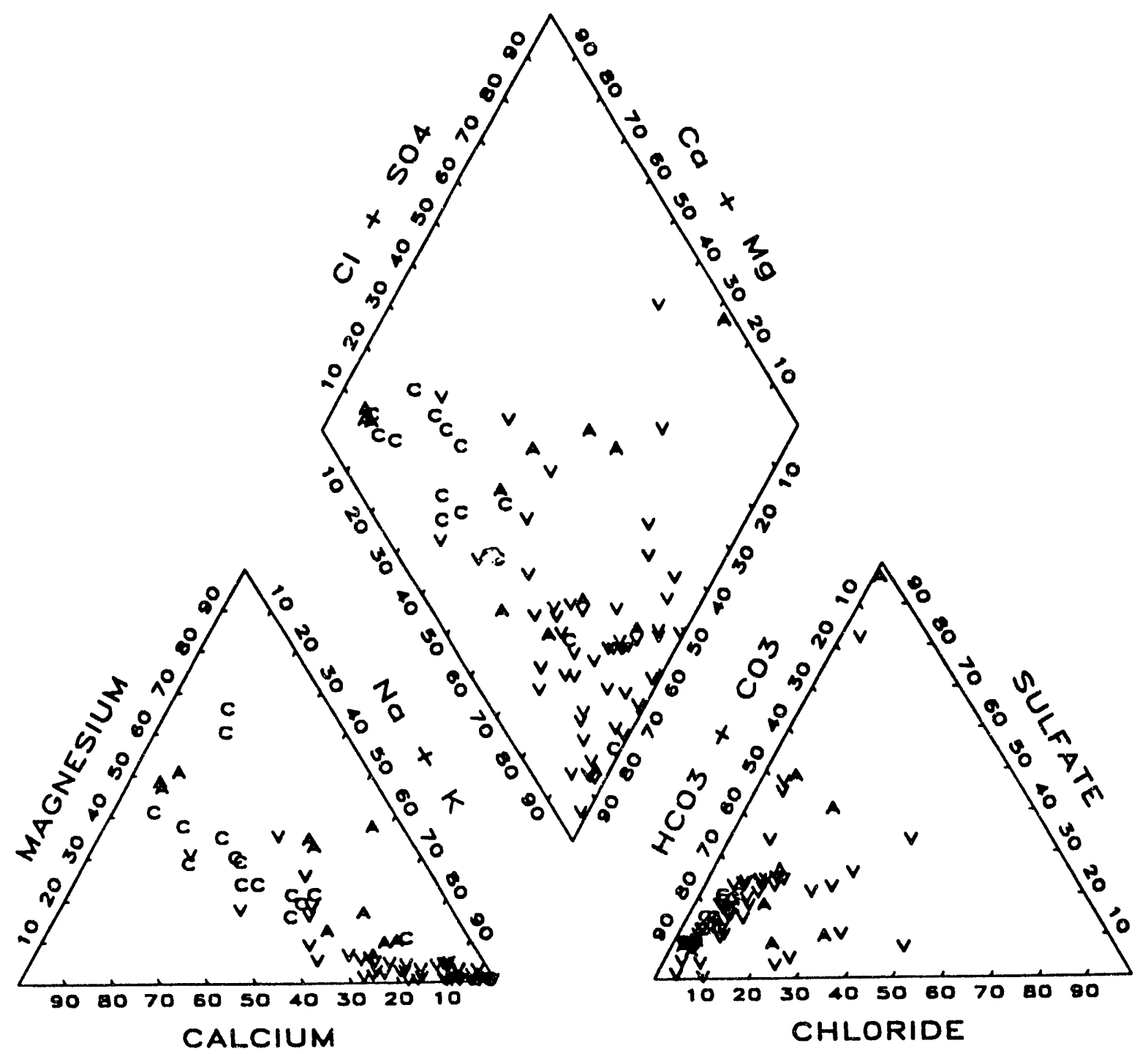

Figure 8. Trilinear diagram showing relative ion percentages for samples collected from all wells reported in this study, differentiated based on aquifer rock type. Aquifer designations are as follows: $A=$ alluvium, $C=$ carbonate, and $V=$ volcanic. Averaged values used to construct this diagram are reported in Appendix $C$. 
has essentially $100 \% \mathrm{Na}+\mathrm{K}$ in terms of cations, making it chemically unlike the other carbonate wells and more similar to the volcanics. Despite such problems, aquifer designations were made based on rock type rather than by second guessing the chemical interpretations to follow.

The chemical data were examined in the context of our present knowledge of the physical flow system. Groundwater flow directions in the NTS area have been suggested based on geologic and geophysical information, water-level data, precipitation data, spring discharge measurements, aquifer test data, as well as water chemistry. Though considerable uncertainty in flow boundaries and inter-unit flow exists, workers have generally agreed on the gross regional groundwater flow directions at the NTS. Flow is believed to move primarily in a north-to-south direction across the NTS with an additional component of northeast to southwest flow (Figure 9). Flow southward through Yucca Flat into Frenchman Flat is joined by a component of westerly flow from Emigrant Valley and other areas east of the NTS. After passing through Mercury Valley, there is a southwestward turn as groundwater moves toward the discharge area in Ash Meadows. Components of groundwater flow beneath Pahute Mesa move southward into the Fortymile Wash structural feature and on to discharge at Alkali Flat and in Death Valley. There is also southwestward flow from Pahute Mesa to Oasis Valley. Flow relationships between the east and west sides of the NTS are less certain, with postulated flow from Pahute/Rainier Mesas into Yucca Flat in the north and possibly from western Yucca and Frenchman Flats to Jackass Flats in the south.

The following sections compare the chemical data for each type of aquifer material with the postulated flow directions discussed above. Well water chemistry is represented on maps using Stiff diagrams. The Stiff diagrams show the geochemical similarities and differences among wells; the cation concentrations are plotted on the left side of each Stiff figure in units of milliequivalents per liter, while the anions are similarly plotted on the right side. The graphical similarities/differences between Stiff diagrams represent the geochemical similarities/differences of the water samples collected from each well (Hem, 1985).

\section{Alluvium Wells}

All wells providing water samples from alluvial material in this study are located either in the eastern part of the NTS or east of the NTS (Figure 10). Regional (interbasin) groundwater flow beneath the eastern part of the NTS is believed to occur only through carbonate rocks (Winograd and Thordarson, 1975). Groundwater in alluvial deposits is isolated in each basin, so regional trends in ion concentrations would not be expected in wells completed in alluvium. For example, USGS Water Well A and UE-6d are in Yucca Flat, while Water Well 5B and Water Well 5C are in Frenchman Flat. Alluvial materials are absent in some locations and unsaturated in others between Yucca and Frenchman Flats so that water cannot flow from UE-6d to Water Well 5B without entering volcanic and carbonate units. This segmentation of alluvial water is reflected in the areal distribution of ions shown on Figure 11. The difference in ion concentrations within an individual basin (e.g., sodium at Water Well 5B is $97 \mathrm{mg} / \mathrm{L}$, while at Water Well $5 C$ it is $129 \mathrm{mg} / \mathrm{L}$ ) is also marked and suggests a lack of well-developed lateral flow systems that would homogenize chemical character within each basin. The logical extension of this observation is that vertical flow dominates 

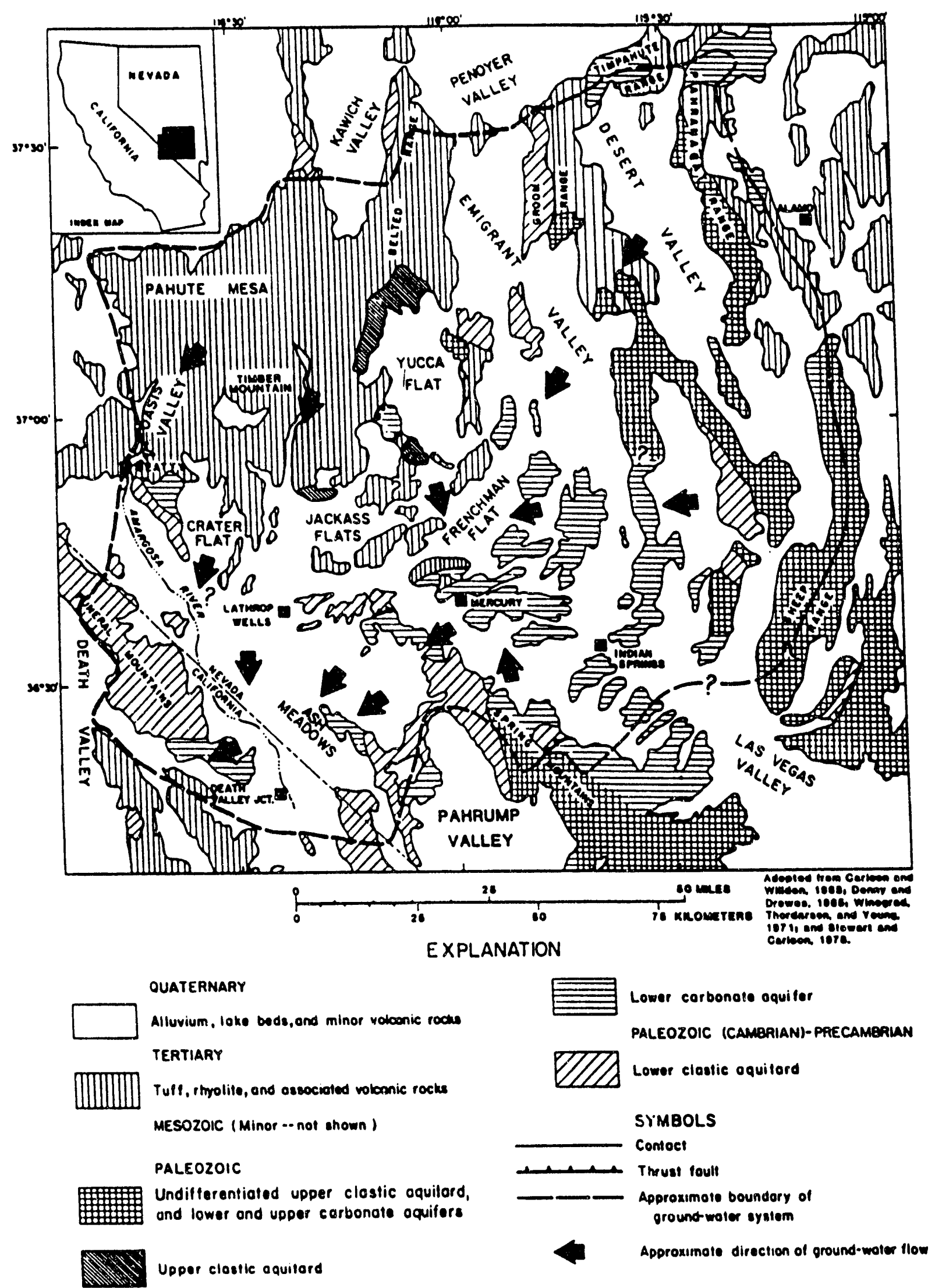

Figure 9. General groundwater flow directions in the NTS area. From Waddell (1982). 


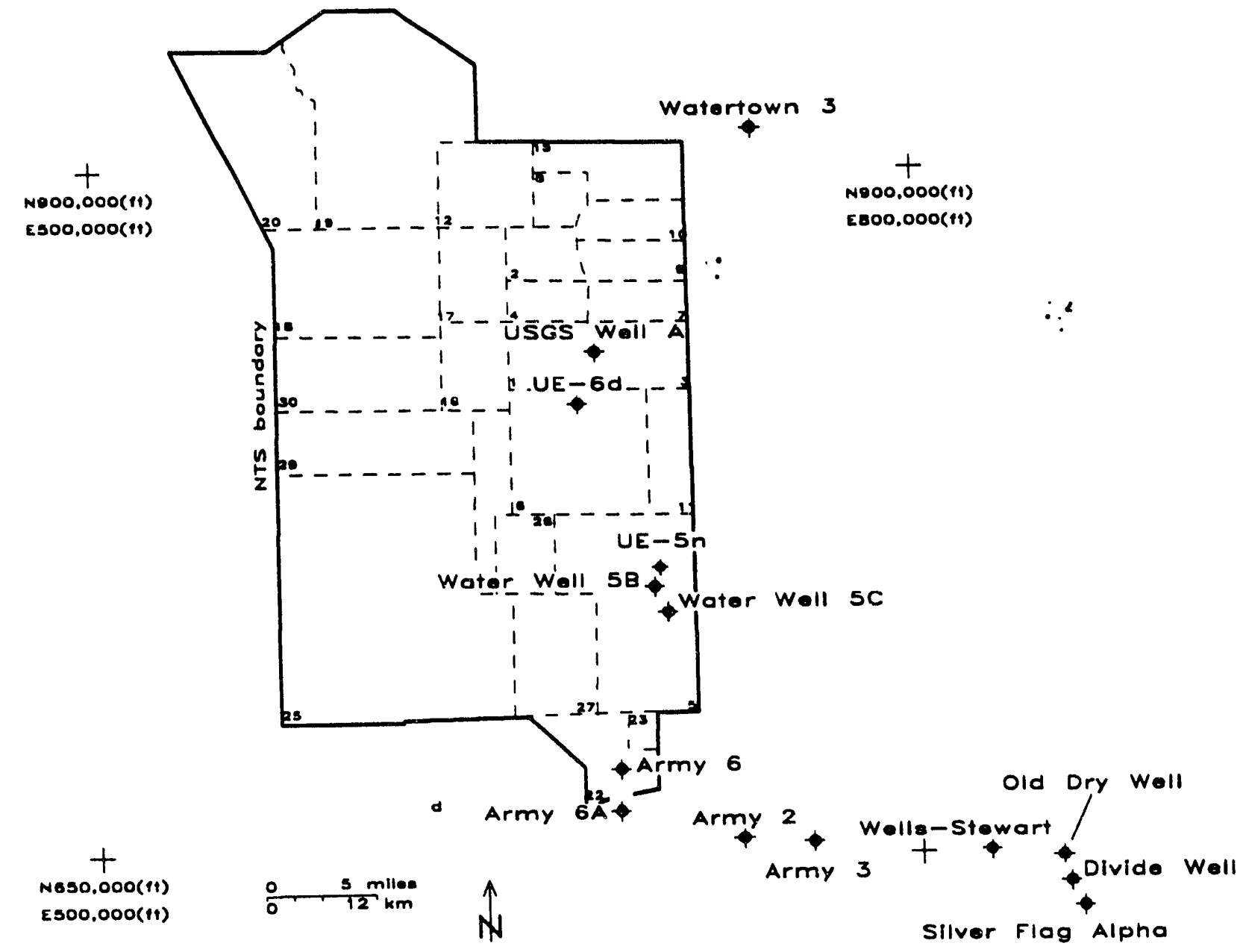

Figure 10. Wells completed in alluvial materials at and near the NTS for which water chemistry data are available. Nevada state coordinates are shown for reference. 


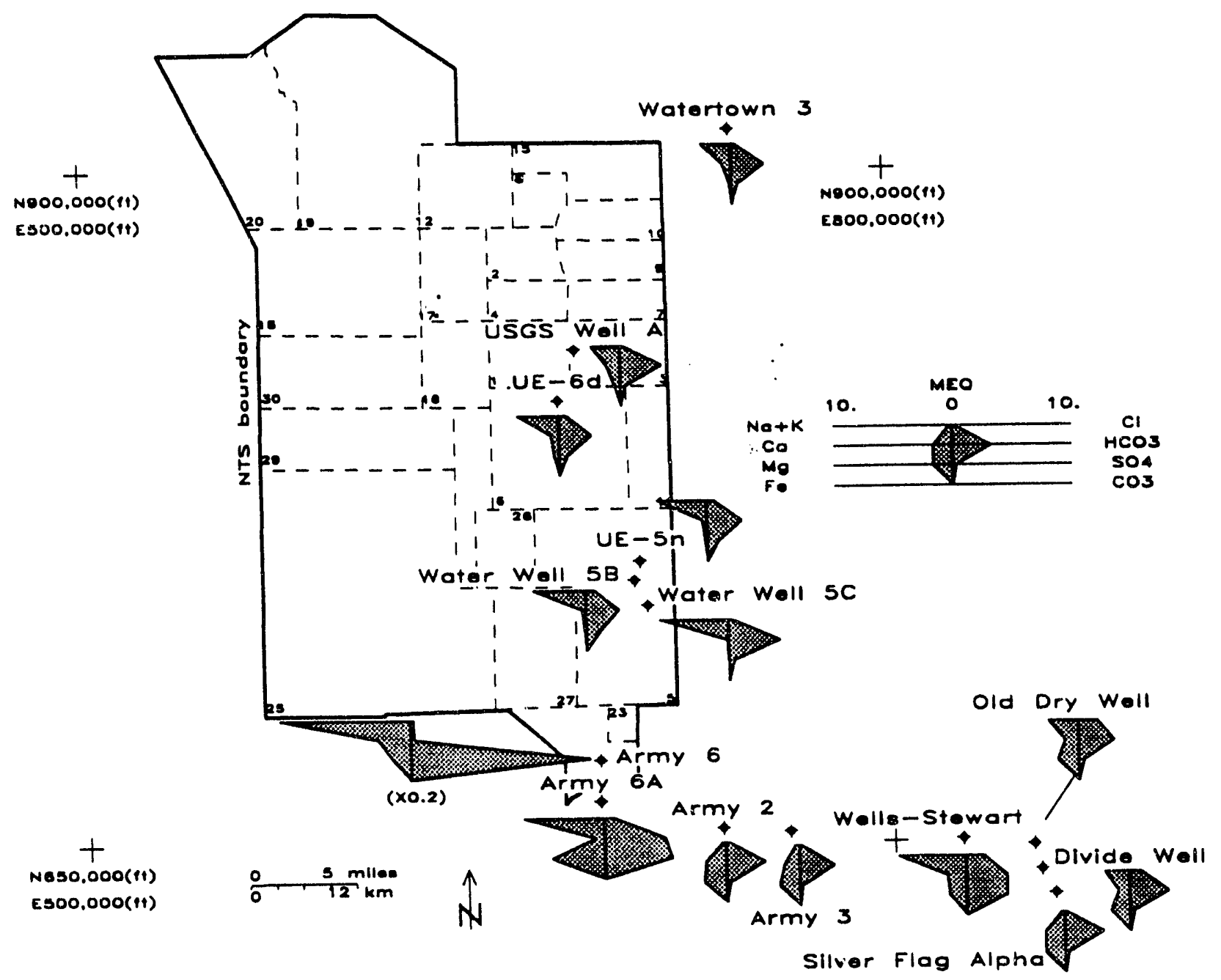

Figure 11. Areal variation in water chemistry for wells completed in alluvial materials, as represented by Stiff diagrams. 
in the alluvium. The one exception appears to be the saturated alluvium in the vicinity of wells Army \#2 and Army \#3, where there is good consistency in ion concentrations.

\section{Carbonate Wells}

As with the alluvium wells, all but one of the carbonate wells for which chemistry data were available are located on the eastern part of the NTS, or east of the NTS (Figure 12). Flow is believed to move through carbonate rocks from the north end of Yucca Flat, through Frenchman Flat and Mercury Valley. A westward flowing component joins this southerly component from the area sampled by USGS HTH \#10 and USGS HTH \#4, and points east, and this combined system moves in a southwestwardly direction toward Ash Meadows. Quartz and Sand Springs, also east of the NTS, occur in the Pintwater Range and represent perched water that does not contribute to the regional flow system. The one western carbonate well, UE-25p \#1, is located in the Fortymile Wash drainage, where flow is believed to be more directly southward to Ash Meadows.

Though the carbonate aquifer is considered a regional aquifer system, the groundwater chemistry reveals that the units intersected by the carbonate wells are not chemically homogeneous. Though some of the variation in ion composition seen on the carbonate map (Figure 13) can be attributed to the lumping of all pre-Tertiary. units for mapping purposes (in particular, UE-15d Water Well, UE-16d Eleana, and UE-16f Eteana are not sampling the lower carbonate aquifer), unaccounted shifts in ion concentrations occur. For example, USGS Test Well D and UE-1c sample carbonate units about $3000 \mathrm{~m}(10,000 \mathrm{ft})$ apart in mid-Yucca Flat. Dissolved chloride is over 1.5 times higher at USGS Test Well D and dissolved sodium is almost three times greater than at UE-1c. UE-1c is located farther to the south (downgradient) and thus would be expected to either have similar or higher dissolved ion concentrations than USGS Test Well D. Moving farther southward along the presumed flow direction, chloride and sodium values increase markedly at USGS Water Well C and Water Well C-1, indicating a contribution of water from volcanic units. Water could be moving into the carbonates by enhanced downward leakage through volcanics and alluvium beneath Yucca Lake or laterally where volcanic units are juxtaposed with carbonates along faults. USGS Water Well C and Water Well C-1 are located in the upper plate of a low-angle thrust fault (Winograd and Thordarson, 1975), which probably abuts volcanic units to the north of the wells. The very old radiocarbon age of water in Water Well C-1 (greater than 30,000 years before present; Boughton, 1986) indicates that the water has had a long residence time, whether derived from lateral or vertical flow. Relatively high chloride and sodium concentrations at UE-25p \#1 similarly indicate a contribution of volcanic water to the carbonate aquifer in the Fortymile Wash area. Saturation calculations show that all of the carbonate waters are saturated with respect to calcite and quartz, whether they have mixed with volcanic water or not.

The wide concentration variations in conservative ions such as chloride and sodium suggest a complex carbonate system possibly containing isolated flow units such as the fault block containing the $\mathrm{C}$ wells. Transmissivity in the lower carbonate aquifer is structurally controlled and known to have a wide range in values. However, hydraulic testing indicates that water-bearing fractures are reasonably well connected, creating a grossly homogeneous aquifer (Winograd and Thordarson, 1975). In addition, Winograd and Thordarson report nearly identical chemical analyses 


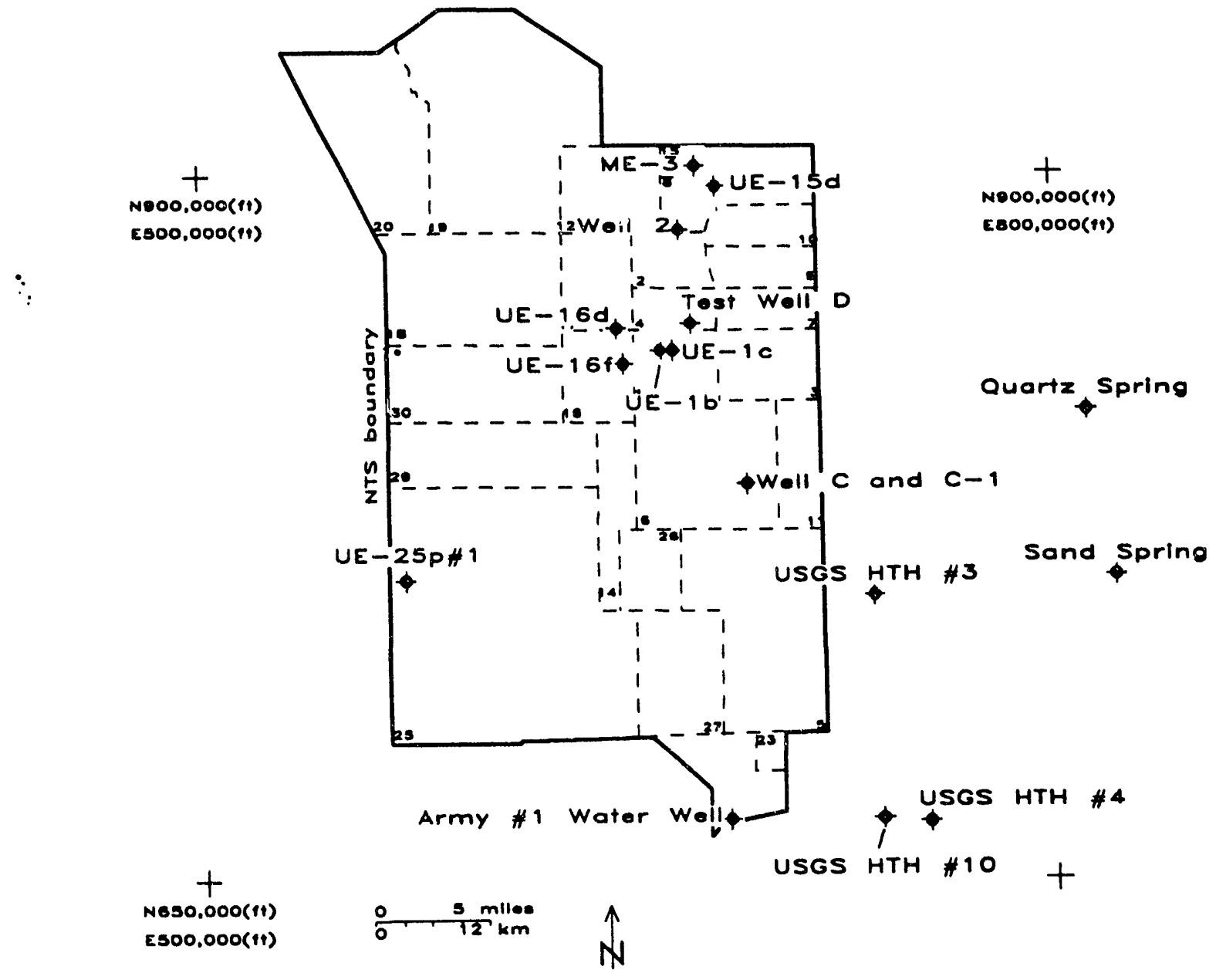

Figure 12. Wells and springs completed in carbonate rocks (or similar formations) at and near the NTS for which water chemistry data are available. Nevada state coordinates are shown for reference. 


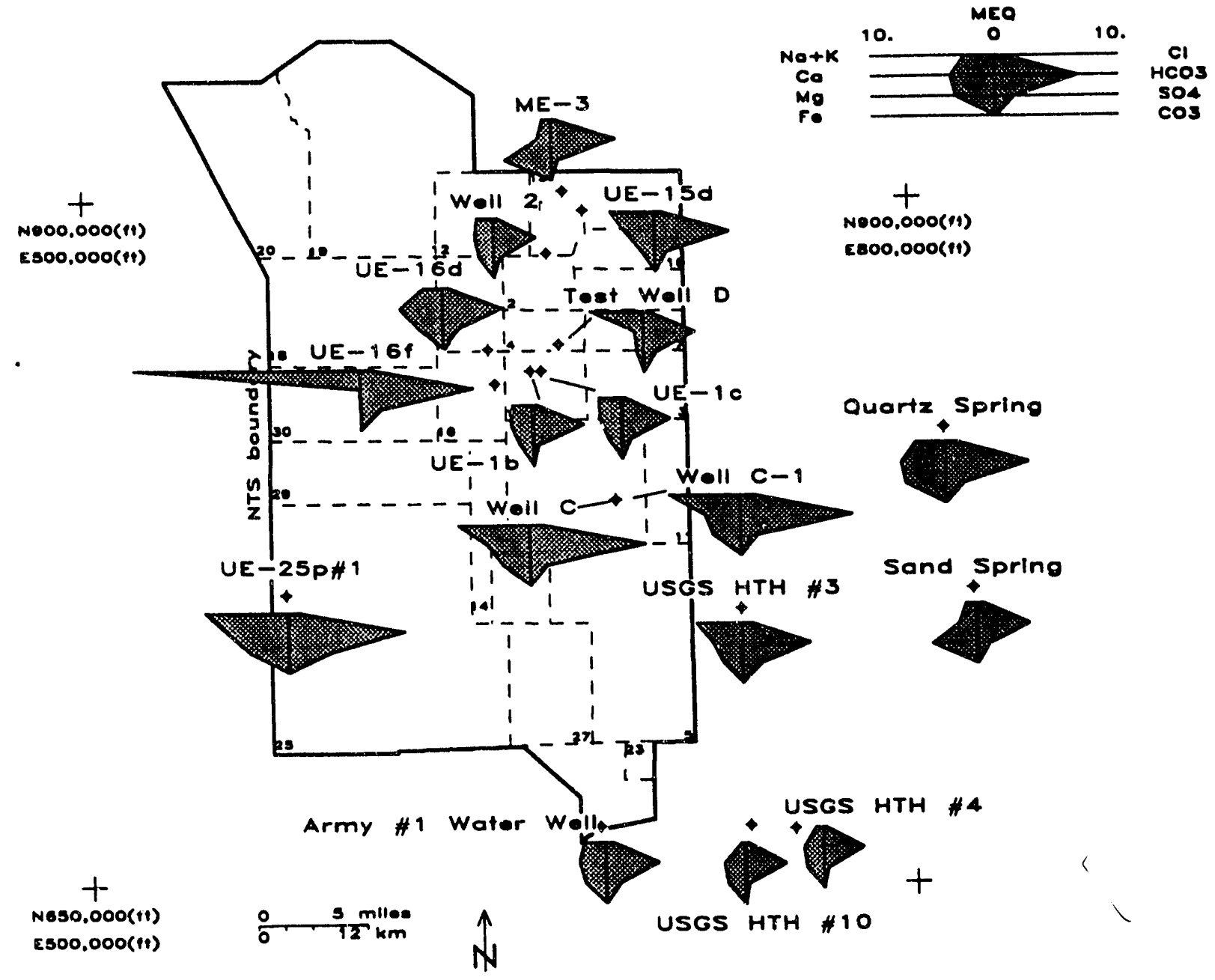

Figure 13. Areal variation in water chemistry for wells and springs completed in carbonate rocks (or similar formations), as represented by Stiff diagrams. 
for water from different formations comprising the lower carbonate aquifer, sampled within a single well. Despite this earlier work, the range in groundwater chemistry in the carbonate aquifer across the eastem portion of the NTS indicates that though the lower carbonate aquifer may be considered a single hydraulic unit in gross flow terms, it may be considerably more complex when considering solute transport.

One feature of the carbonate hydrochemical map that can be explained is the significant decrease in dissolved ion concentrations that occurs between the south end of Yucca Flat and Mercury Valley, as typified by the halving of chloride and reduction by two-thirds in sodium concentrations from USGS Water Well C to Army \#1 Water Well. Such a reduction in conservative ions could only occur with the addition of a lower salinity water to the system. Leakage from the alluvium and volcanic aquifers in Frenchman Flat cannot be a source of dilution because sodium concentrations are muck higher in those units than those at Army \#1 Water Well. A more likely source of 'silution, suggested by most flow models, is the movement of water from points east and south in the carbonate units. Groundwater in the USGS HTH \#4 and \#10 area probably originates as recharge in the northern Spring Mountains (Byer, 1991; and Sadler et al., 1991). The low salinity and relatively low calcite saturation index at these wells supports the relatively young ages (approximately 5000 years) calculated for groundwater in the area using a discrete-state compartment model (Sadler et al., 1991). Using ion concentrations averaged between those of USGS HTH \#10 and USGS HTH \#4 to represent underflow from the east, the relative contributions from Yucca Flat (as represented by USGS Water Well $C$ and Water Well $C-1$ ) and :he eastern area required to produce the water sarnpled from Army \#1 Water Well are approximately $30 \%$ water irom Yucca Fiat and $70 \%$ water from the east. These approximate percentages are upheld by all of the major ion concentrations with the exception of sulfate (Table 1). Several other wells in the vicinity of Army \#1 Water Well have high sulfate concentrations (Army 6 and Army 6A), suggesting a local source for dissolved sulfate, either from hydrothermally altered .ocks or gypsum deposits.

Table 1. Dissolved ion concentrations in $\mathrm{mg} / \mathrm{L}$ for wells in three areas of the carbonate aquifer and calculated mass percentages needed to create water at Army \#1 Water Well from the nther two typss.

\begin{tabular}{lccccc}
\hline Ion & $\begin{array}{c}\text { Concentration } \\
\text { in Well C }\end{array}$ & $\begin{array}{c}\text { Concentration } \\
\text { in HTH 4 \& 10 }\end{array}$ & $\begin{array}{c}\text { Concentration } \\
\text { in Army \#1 }\end{array}$ & $\begin{array}{c}\text { Percent from } \\
\text { Yucca Flat }\end{array}$ & $\begin{array}{c}\text { Percent from } \\
\text { east of NTS }\end{array}$ \\
\hline $\mathrm{Ca}$ & 65 & 36 & 44 & 35 & 65 \\
$\mathrm{Mg}$ & 28 & 18 & 21 & 30 & 70 \\
$\mathrm{Na}$ & 125 & 10 & 38 & 25 & 75 \\
$\mathrm{~K}$ & 14 & 2 & 5 & 30 & 70 \\
$\mathrm{Cl}$ & 32 & 6 & 16 & 40 & 60 \\
$\mathrm{SO}_{4}$ & 65 & 16 & 53 & 75 & 25 \\
$\mathrm{HCO}_{3}$ & 555 & 197 & 257 & 15 & 85 \\
\hline
\end{tabular}


Another possible explanation for the difference between the " $C$ " wells and Army \#1 Water Well is that water from USGS Water Well C and Water Well C-1 is not representative of the carbonate water composition leaving Yucca Flat. This would assume that the well C structural block is isolated from the rest of the flow system and that flow from Yucca Flat is typified by the composition of water from Water Well 2, UE-1b, and UE-1c. This scenario would allow little or no contribution of water from the east, and is not compatible with the conceptual groundwater flow models.

\section{Volcanic Wells}

Wells that penetrate volcanic units are found throughout the NTS (Figures 14 and 15). In the eastern area, coincident with the areas where there are alluvium and carbonate wells, the volcanic aquifers are not believed to form continuous interbasin flow units. As with groundwater in the alluvium, it is believed that water in the volcanics must discharge to the carbonate aquifer to flow from Yucca Flat to Frenchman Flat and then to Mercury Valley. Spatial variations in ion concentrations from these wells suggest the absence of a well-integrated lateral groundwater flow system (Figure 16). One general pattern is suggested by the data, however. Wells on the west side of Yucca and Frenchman Flats tend to have higher calcium and magnesium concentrations and lower $\mathrm{pH}$ values than wells to the east. This is balanced by lower sodium concentrations and/or higher chloride and sulfate concentrations. The wells showing the higher calcium and magnesium values are USGS HTH "F", Pluto 1, Pluto 5, UE-1a, and to a lesser extent Well 3 and Water Well \#4. An exception to this trend is well $\mathrm{UE}-14 \mathrm{~b}$, located in Mid Valley, which does not have notably high calcium and magnesium concentrations, but does have higher sulfate than the eastern wells. The higher calcium and magnesium concentrations in the western Yucca and Frenchman wells (UE-1a, Well 3, Water Well \#4) may reflect the movement of groundwater into volcanic units from the upper carbonate aquifer in the structurally complex area along the Eleana Formation subcrop bounding western Yucca Flat. The impact of hydrothermally altered rocks is believed to account for the higher sulfate concentration in J-11, USGS HTH "F" and possibly UE-14b. The Pluto wells sample perched water that probably receives calcium via surface recharge processes.

A lack of intrabasin chemical continuity is particularly noteworthy in Frenchman Flat where both sodium and bicarbonate are twice as high in Water Well 5A than in UE-5c Water Well, less than $10 \mathrm{~km}$ (six miles) to the north. In this cas, and perta. nthers, structural features may have isolated the volcanic units. Water Well 5A is on the opp " ade of the Rock Valley Fault System from $\mathrm{UE}-5 \mathrm{c}$ Water Well and a $4 \mathrm{~m}$ (13 ft) difference in he:as . dlues attests to some hydraulic discontinuity between the two areas.

Though chemical variations in water from volcanic wells on Pahute Mesa are generally less than variations found elsewhere on the NTS, ion concentrations in well water on the Mesa do not vary in any pattern consistent with postulated flow directions (Figure 17). This may indicate that the complex secuence of volcanic units beneath Pahute Mesa does not constitute a single, unified flow system. Within the saturated zone, the vertical and horizontal distribution of permeable ash-fall and ash-flow tuffs and lava flows that comprise the aquifers of Pahute Mesa is highly variable, even over short distances. This stratigraphic variability, coupled with structural control of groundwater flow th rough fractures in a complex caldera environment, results in a hydrologic system that does 


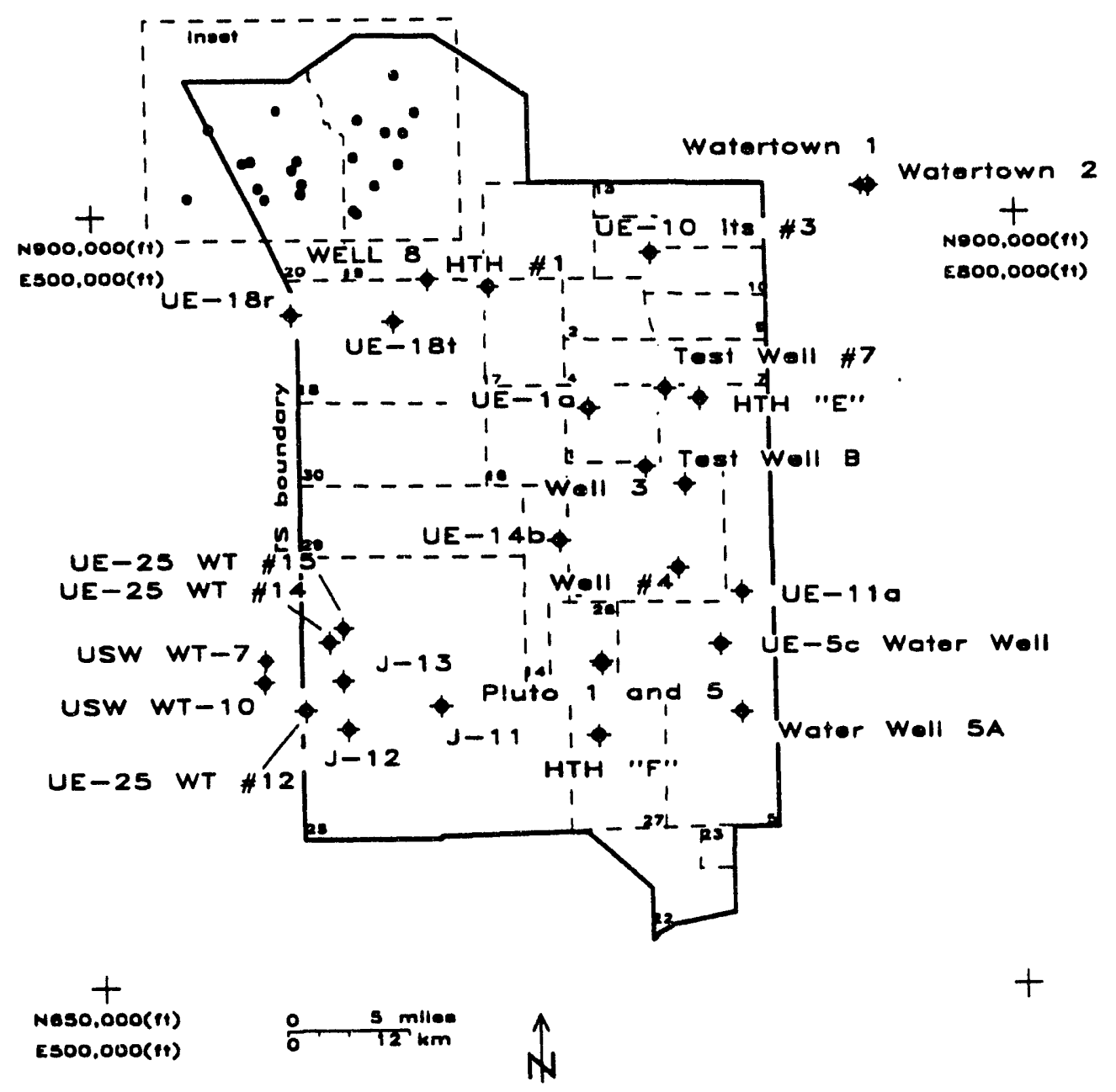

Figure 14. Wells completed in volcanic rocks at and near the NTS for which water chemistry data are available. Well names for the Pahute Mesa area can be found on Figure 15. Nevada state coordinates are shown for reference. 


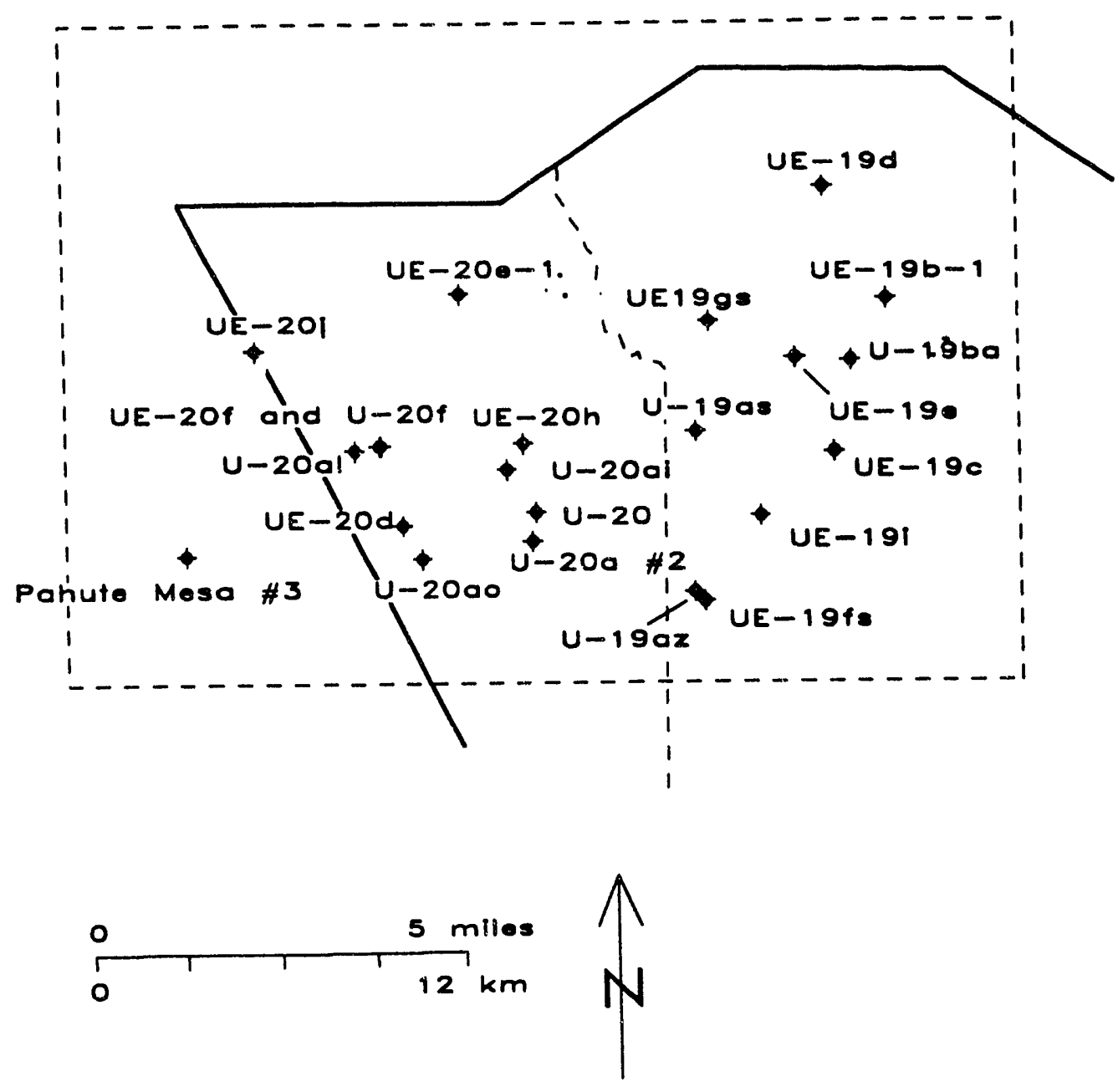

Figure 15. Wells completed in volcanic rocks on Pahute Mesa for which water chemistry data are available. For location relative to the NTS, see Figure 14. 


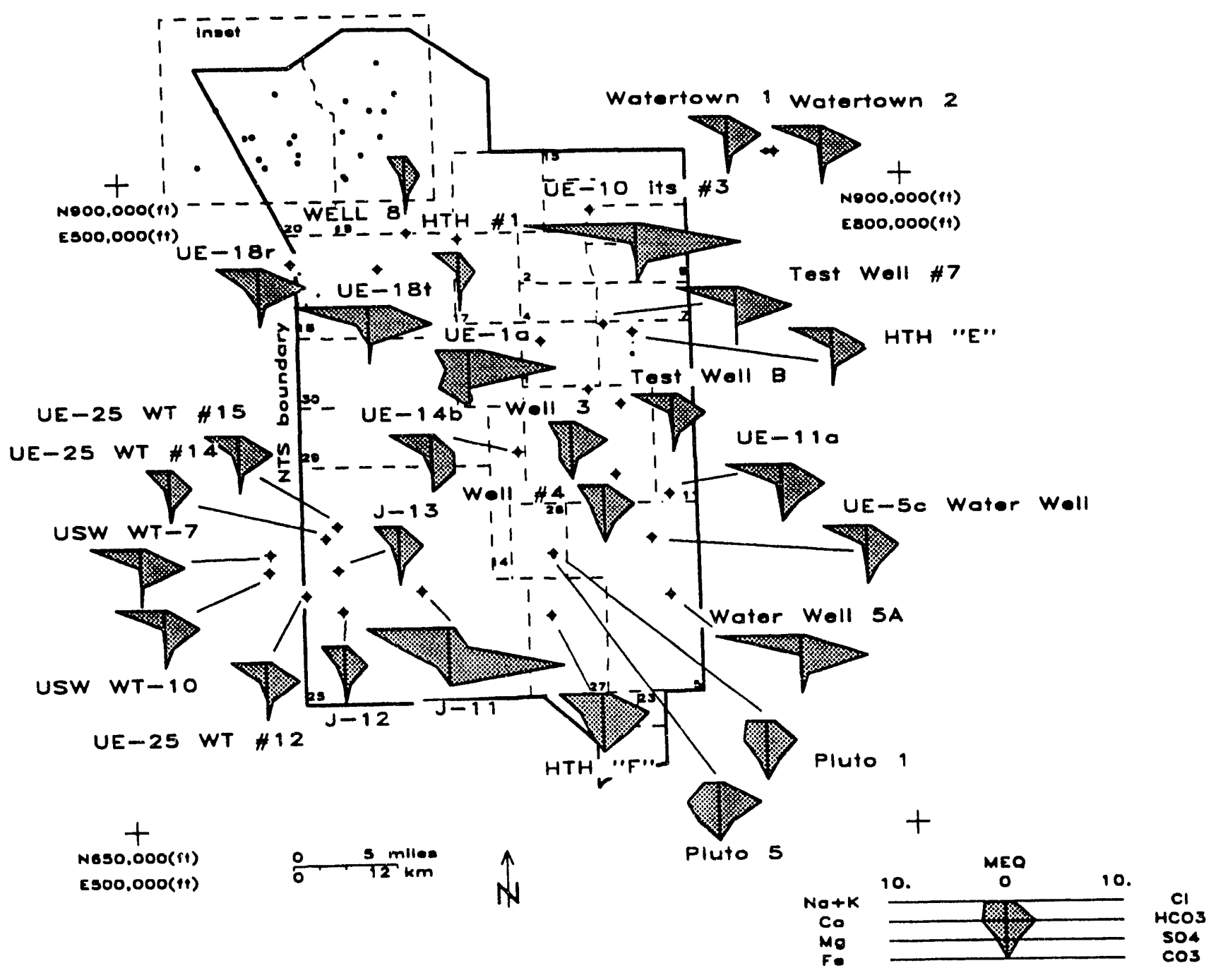

Figure 16. Areal variation in water chemistry for wells completed in volcanic rocks, as represented by Stiff diagrams. The Pahute Mesa area is shown separately on Figure 17 for clarity. 

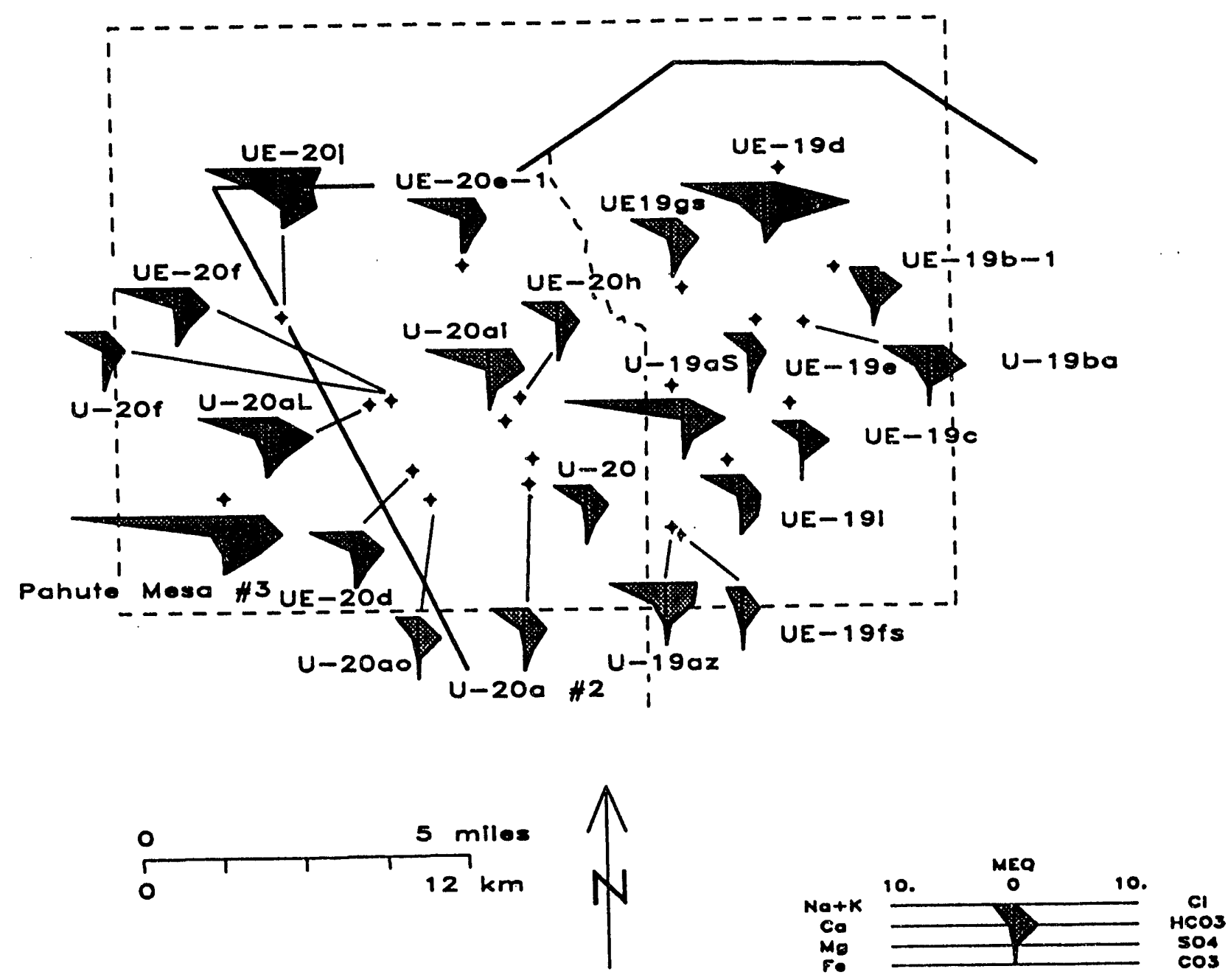

Figure 17. Areal variation in water chemistry for wells completed in volcanic rocks on Pahute Mesa, as represented by Stiff diagrams. 
not have predictable continuity in lateral directions. The apparent lack of consistent chemical changes in downgradient directions may actually result from an incomplete understanding of flow path directions. In addition, some variability results from sampling perched horizons that may have been contaminated by drilling fluid (at U-19ba and U-19az).

Blankennagel and Weir (1973) observed that hydraulic heads decreased with depth beneath the eastern part of Pahute Mesa (indicating a potential for downward flow) and that heads increased with depth beneath western Pahute Mesa. In addition, they also observed that while sodium and bicarbonate were the dominant ions in all Pahute Mesa groundwater, there was proportionally more calcium in the area of downward flow and more sulfate and chloride in the zone of upward flow. The new data blur the distinction for cations, but the difference in anions is similar (Figure 18). Sulfate is often associated with hydrothermal alteration and is consistent with an area where deeper, older water is moving upward in the groundwater system.

Another cluster of volcanic aquifer samples is located in the southwest corner of the NTS (Figure 16). A major hydrologic feature in this area is Fortymile Wash, which is believed to mark a zone of higher hydraulic conductivity and greater recharge (Byer, 1991; Sadler et al., 1991). With the newer samples, the chemical similarity between J-12 Water Well and J-13 Water Well can now be extended further north along the wash to UE-25 WT \#14, which has an ionic composition very similar to the downgradient wells. Even farther to the north, UE-25 WT \#15 is also similar to the other Fortymile Wash samples but has a higher percentage of sodium and bicarbonate. Well UE-18t is located much farther north, near the head of the wash and has a greater dissolved ion content than the southern Fortymile Wash wells. The lower salinity of the downgradient wells may reflect the diluting effect of infiltrating recharge along the length of the wash.

The southern Fortymile Wash wells have about five times the amount of calcium and over 10 times the amount of magnesium as the two wells (USW WT-7 and USW WT-10) in the drainage basin west of Yucca Mountain. The western wells have a dominantly $\mathrm{Na}-\mathrm{HCO}_{3}$ signature characteristic of water from volcanic aquifers. The higher concentration of calcium and magnesium in the Fortymile Wash area may indicate a contribution of water from underlying carbonate rocks, infiltration of rainfall that dissolves near-surface calcium deposits, or mixing with water from areas east of Fortymile Wash, where higher dissolved ion concentrations are attributed to interaction with hydrothermally altered rocks. Groundwater from $\mathrm{J}-11$ represents this higher $\mathrm{Ca}-\mathrm{SO}_{4}$ water, which is also found at USGS HTH "F." The chemistry of the carbonate water in Fortymile Wash, as sampled by UE-25p\#1, indicates mixing of volcanic water into the carbonate unit rather than movement of water from the carbonates to volcanics. Either this mixing occurs outside the area sampled by the volcanic wells (e.g., where the carbonates abut the nearby caldera complexes), or the calcium and magnesium in the volcanic wells must be from one of the sources other than the underlying carbonate. Based on geochemical and isotopic data, Matuska (1989) concluded that flow from the carbonates into the volcanics in the Fortymile area was unlikely. 


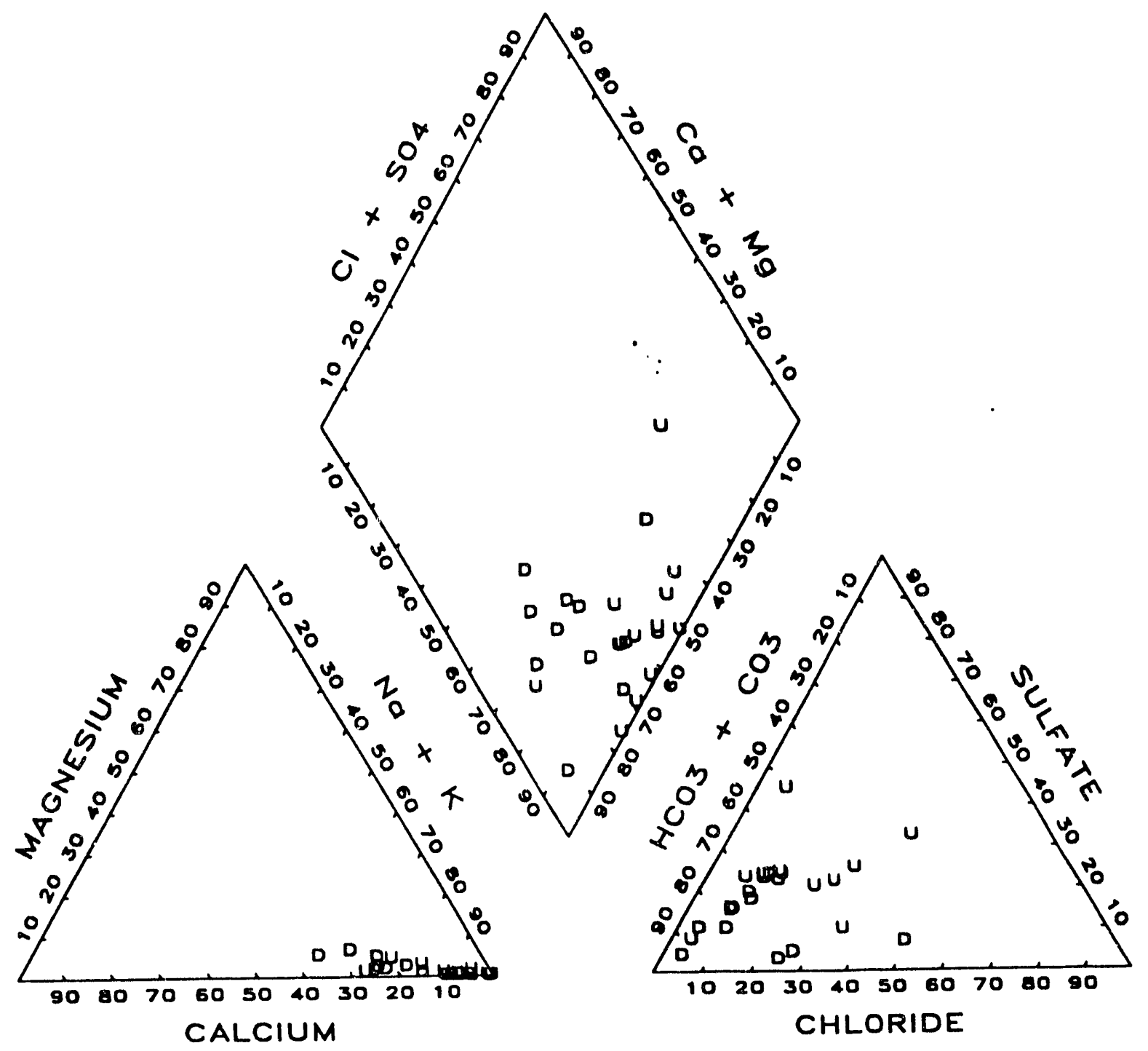

Figure 18. Trilinear diagram showing relative ion percentages for samples collected from volcanic aquifers on Pahute Mesa, differentiated based on their location relative to the areas of downward ("D") and upward ("U") flow defined by Blankennagel and Weir (1973). 


\section{CONCLUSIONS}

Groundwater samples from 81 locations at and around the NTS have been analyzed for major disso!ved constituents. Twenty-seven of these locations are new additions sampled by DRI after publication of major interpretive reports by the USGS. Eighteen locations were sampled by both DRI and the USGS with generally excellent agreement between results. Most cases with discrepancies can be explained by continued well development or changes in well completion over the years.

The new data support the occurrence of three hydrochemical facies in the NTS area, identified by previous workers. The distribution of these facies, in particular the presence of mixed cation water in the carbonates, has led to significant conclusions regarding gross groundwater flow by suggesting the movement of water from volcanic aquifers into the carbonate aquifer. However, when examined in detail, the hydrochemistry of the samples in this study is not fully compatible with concepts of regional lateral flow in the carbonate aquifer. There are wide variations in concentrations in generally conservative ions that suggest that though the carbonate aquifer may be considered a single hydrologic unit in gross flow terms, it may be considerably more complex when considering solute transport. The chemistry in wells at the south end of Yucca Flat and near Fortymile Wash indicates a greater contribution of water from volcanic units to the carbonate aquifer in these areas than found elsewhere at the NTS. Ionic concentrations indicate that at the southern end of the NTS, the majority of water in the carbonate system originated from areas east and south of the NTS, with only about $30 \%$ of the water coming from southern Yucca Flat.

While differences in chemistry in alluvium and volcanic wells between basins in the eastern NTS were expected because of a lack of interbasin flow, the absence of homogeneous chemical character within single basins suggests a lack of well-developed lateral flow systems and dominance of vertical groundwater flow in these units within each basin. Relatively higher calcium and magnesium in volcanic wells in the south-central part of the NTS (west side of Yucca and Frenchman Flats and east side of Jackass Flats) may reflect movement of water from the upper carbonate aquifer into the volcanics and contributions from hydrothermally altered areas. The low-calcium water found in eastern Yucca and Frenchman Flats and west of Yucca Mountain is typical of water that has encountered primarily volcanic material along its flowpath. Consistent chemical patterns could not be identified in the volcanic aquifers of Pahute Mesa, presumably because of complex stratigraphic and structural controls. In the southwestern part of the NTS, chemical homogeneity supports groundwater flow in volcanic units along Fortymile Wash, while the calcium and magnesium concentrations suggest a contribution of water from hydrothermally altered rocks in the area east of Fortymile Wash or from infiltration of rainfall that dissolved nearsurface calcium deposits.

\section{REFERENCES}

Benson, L.V. and P.W. McKinley, 1985, Chemical Composition of Ground Water in the Yucca Mountain Area, Nevada, 1971-84. U.S. Geological Survey Open-File Report 85-484, 10 p. 
Blankennagel, R.K. and J.E. Weir, Jr., 1973, Geohydrology of the Eastern Part of Pahute Mesa, Nevada Test Site, Nye County, Nevada. U.S. Geological Survey Professional Paper 712-B, 35p.

Boughton, C.J., 1986, Integrated Geochemical and Hydraulic Analyses of Nevada Test Site Ground Water Systems. University of Nevada, Reno, unpublished Master's thesis, 135p.

Byer, Jr., R.M., 1991, A Carbon-14 Calibrated Discrete-State Compartment Model of the Groundwater Flow System, Yucca Mountain and Vicinity, Nevada-California. University of Nevada, Reno, Master's thesis, 249 p.

Dinwiddie, G.A. and J.E. Weir Jr., 1979, Summary of Hydraulic Tests and Hydrologic Data for Holes UE16d and UE-16f Eleana, Syncline Ridge Area, Nevada Test Site. U.S. Geological Survey, USGS-1543-3, 21p.

Hem, J.D., 1985, Study and Interpretation of the Chemical Characteristics of Natural Waters. U.S. Geological Survey, Water Supply Paper 2254, 263p.

Lyles, B.F., 1990, Tritium Variations in Groundwater on the Nevada Test Site. Desert Research Institute, Water Resources Center Publication \#45086, 85p.

Lyles, B.F., 1992, Letter Report: Report on the Comparison of DRI and EPA Analyses of Tritium. Desert Research Institute, Water Resources Center, prepared for the U.S. Department of Energy, 7 .

Lyles, B.F., W.A. McKay, J.B. Chapman and S.W. Tyler, 1991, Hydrogeologic Characterization of Wells HTH-1, UE18r, UE6e, and HTH-3, Nevada Test Site. Desert Research Institute, Water Resources Center Publication \#45087, U.S. Department of Energy Report DOE/NV/10845-08, UC-703, 73 p.

Matuska, N.A., 1989, The Relationship of the Yucca Mountain Repository Block to the Regional Ground-Water System: A Geochemical Model. University of Nevada, Las Vegas, Master's thesis, $199 \mathrm{p}$.

Moore, J.E., 1962, Selected Logs and Drilling Records of Wells and Test Holes Drilled at the Nevada Test Site Prior to 1960. U.S. Geological Survey Trace Elements Investigations Report TEI-804, $54 \mathrm{p}$.

Robinson, B.P. and W.A. Beetem, 1965, Chemical Data on Water From Supply Wells, Nevada Test Site. U.S. Geological Survey Technical Letter NTS-104, 41 p.

Sadler, W.R., M.E. Campana, R.L. Jacobson and N.L. Ingraham, 1991, A Deuterium-Calibrated, Discrete-State Compartment Model of Regional Groundwater Flow, Nevada Test Site and Vicinity. Desert Research Institute, Water Resources Center Publication \#45088, U.S. Department of Energy Report DOE/NV/10845-09, UC-703, 84 p.

Schoff, S.L. and J.E. Moore, 1964, Chemistry and Movement of Ground Water, Nevada Test Site. U.S. Geological Survey Trace Elements Investigations Report TEI-838, 75p. 
Thordarson, W., M.S. Garber and G.E. Walker, 1962, Ground Water Test Well D, Nevada Test Site, Nye County, Nevada. U.S. Geological Survey Trace Elements Investigations Report TEI-803, 58p.

Waddell, R.K., 1982, Two-Dimensional, Steady-State Model of Ground-Water Flow, Nevada Test Site and Vicinity, Nevada-California. U.S. Geological Survey Water Resources Investigations 82-4085, 71p.

Winograd, I.J. and W. Thordarson, 1975, Hydrogeologic and Hydrochemical Framework, South-Central Great Basin, Nevada-California, with Special Reference to the Nevada Test Site. U.S. Geological Survey Professional Paper 712-C, 126p.

Young, R.A., 1965, Records of Wells and Test Holes Drilled at the Nevada Test Site and Vicinity Since 1960. U.S. Geological Survey Technical Letter NTS-117, 16p. 


\section{APPENDIX A}

Water chemistry data from samples collected between 1957 and 1977 from wells at and near the NTS. Data are from the USGS, with data sources listed in the text. Well names are consistent with those used in the 1991 edition of the Raytheon Services Nevada "NTS Drilling and Mining Summary." Wells are in order of increasing Nevada state north coordinate. 







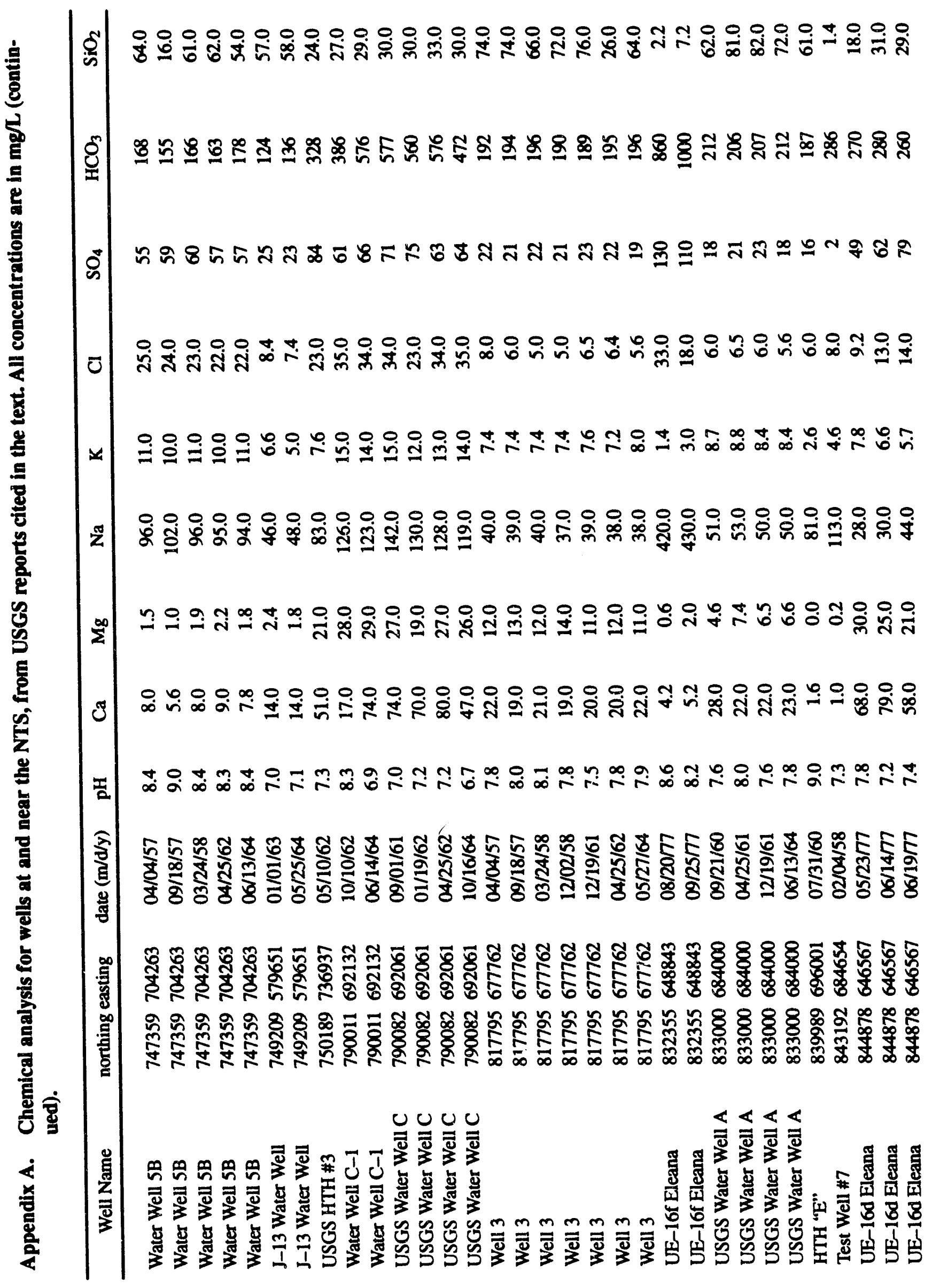




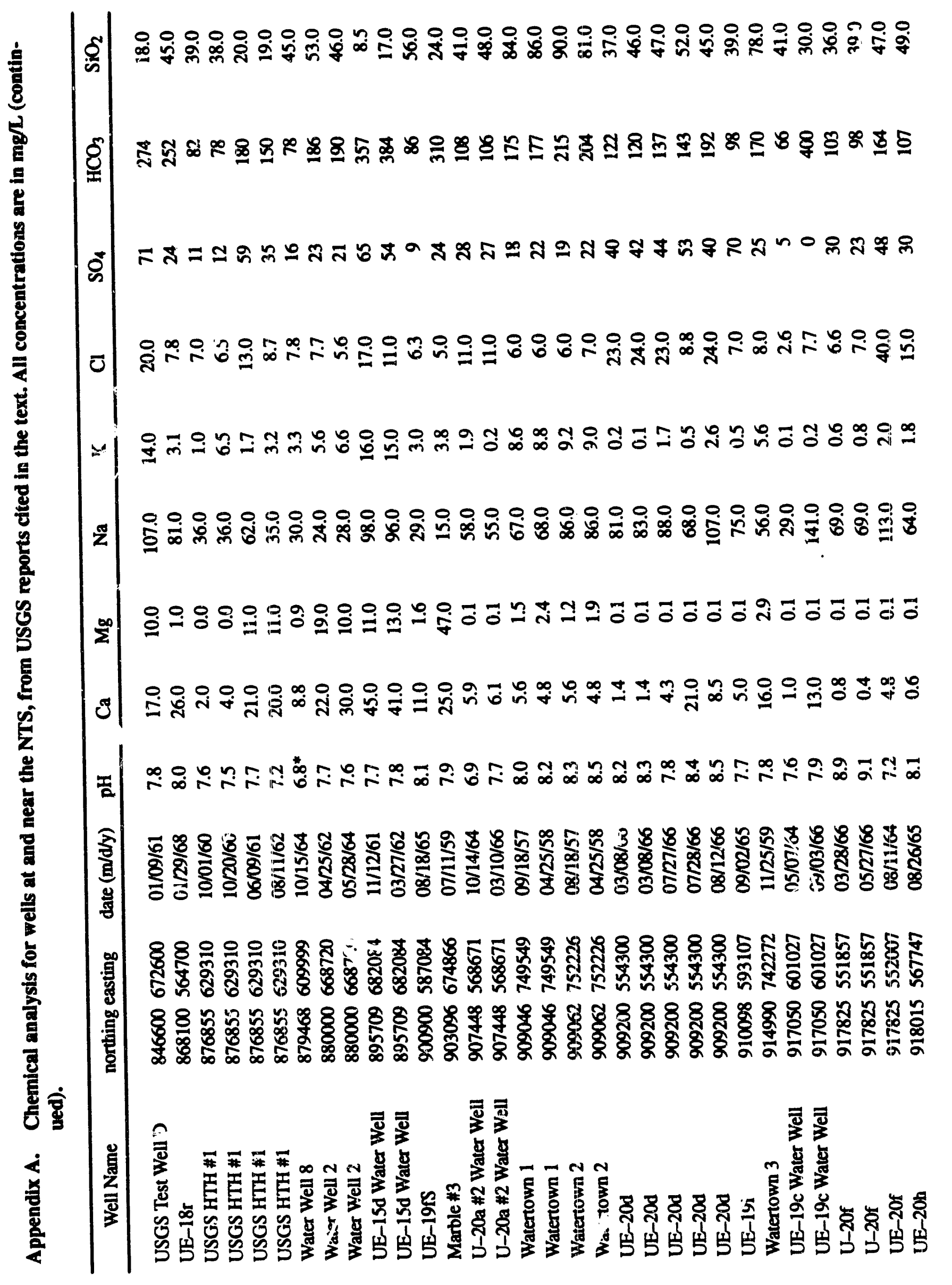




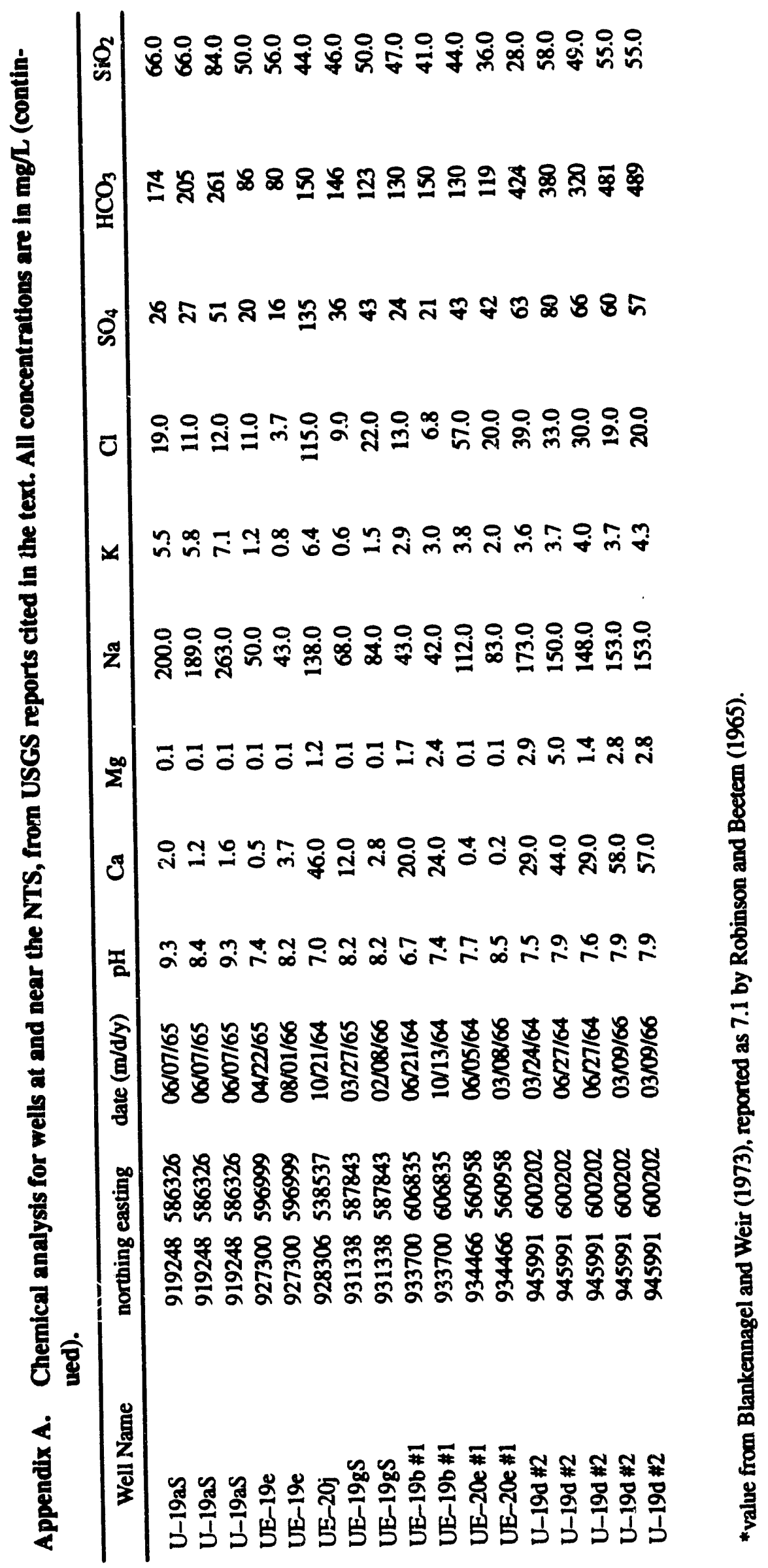




\section{APPENDIX B}

Water chemistry data from samples collected between 1983 and 1990 from wells at and near the NTS. Samples were collected and analyzed by DRI. Well names are consistent with those used in the 1991 edition of the Raytheon Services Nevada "NTS Drilling and Mining Summary." Wells are in order of increasing Nevada state north coordinate. 


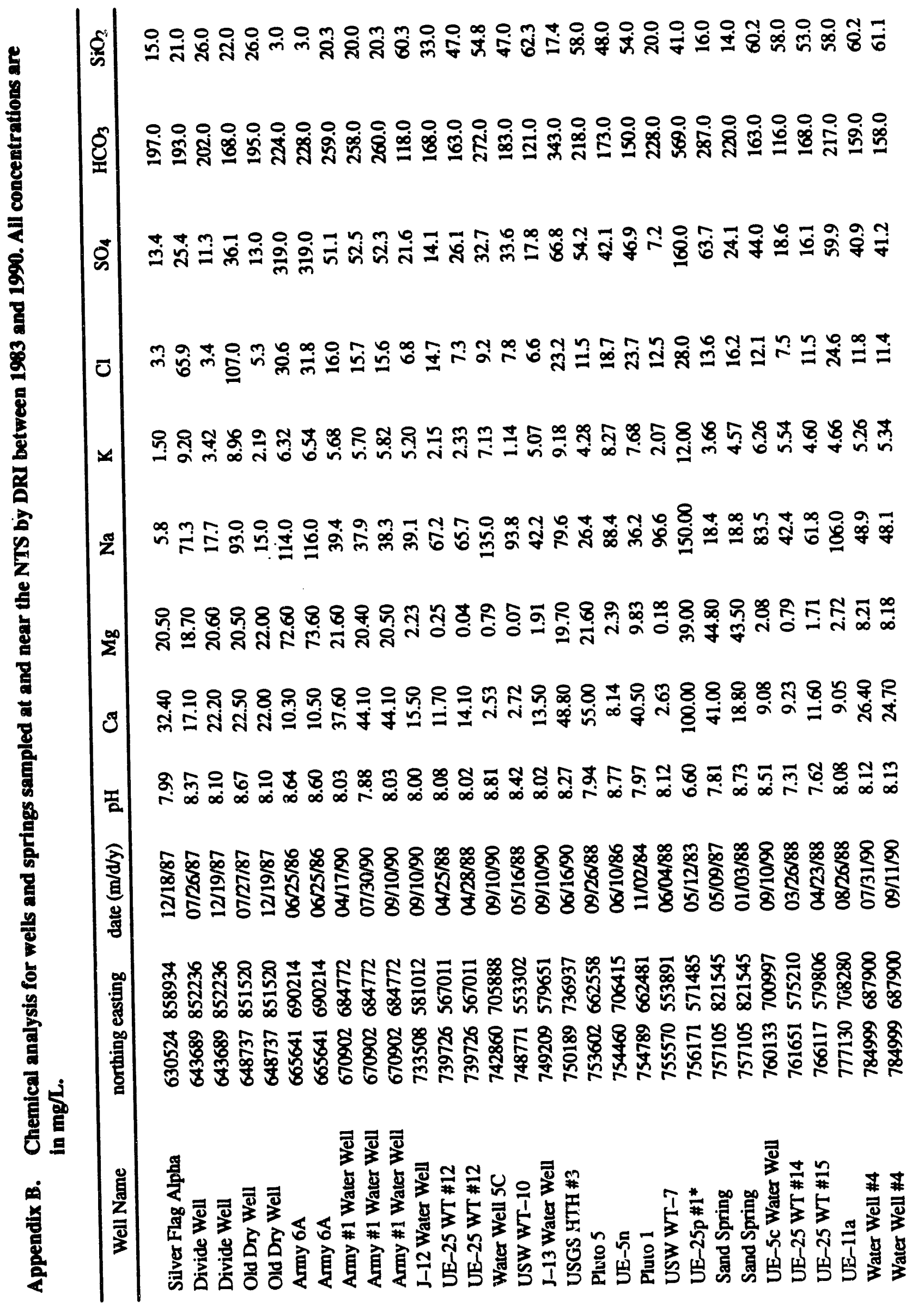




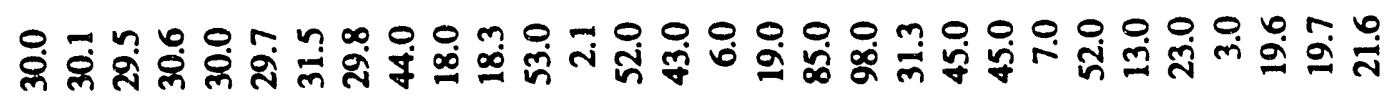

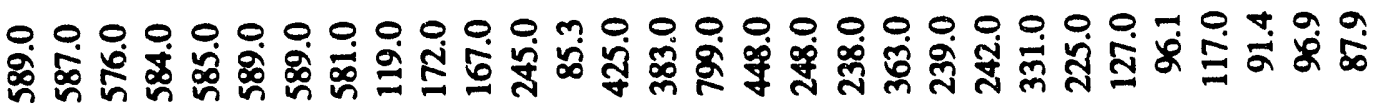

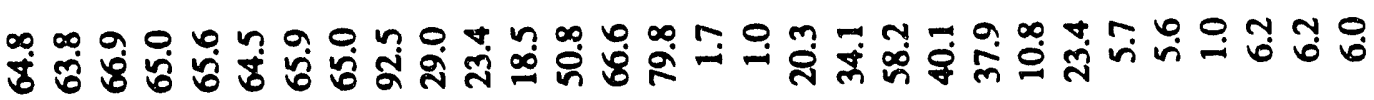

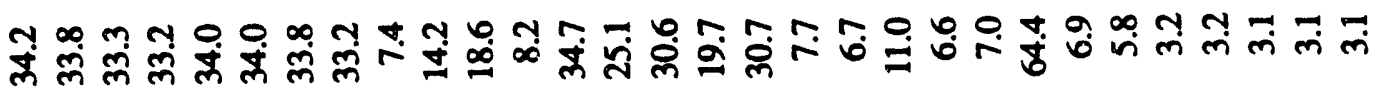

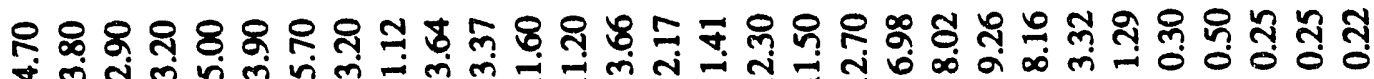

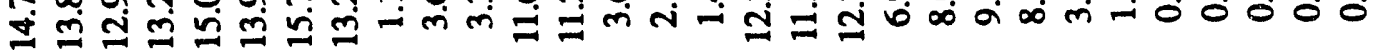

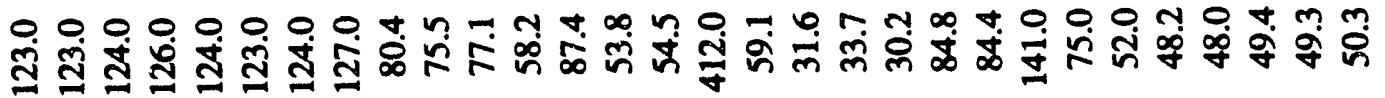

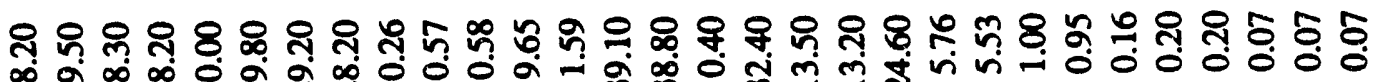

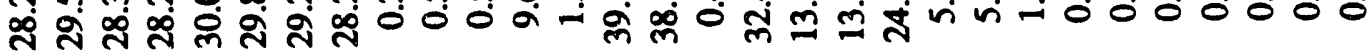

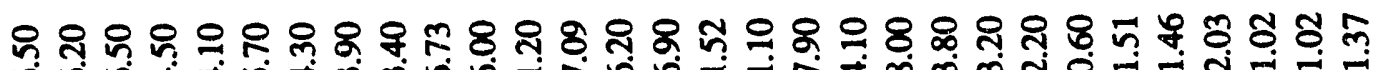

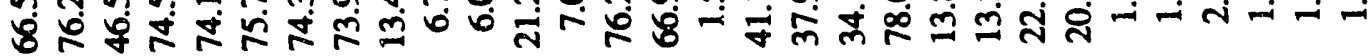

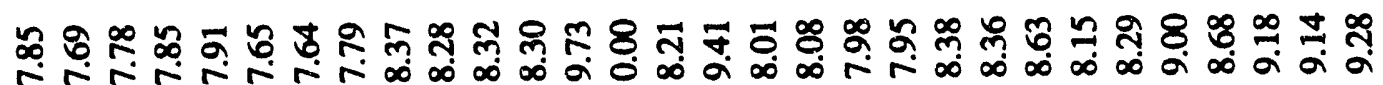

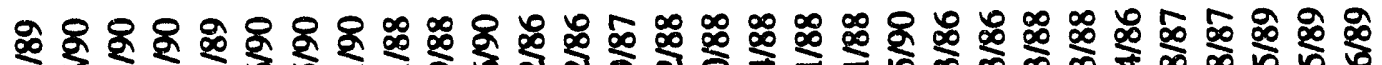

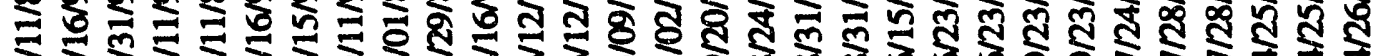

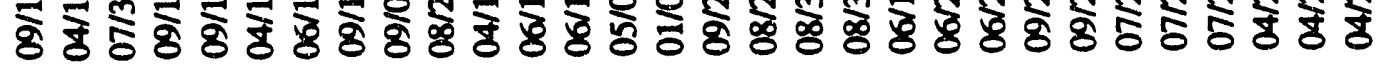

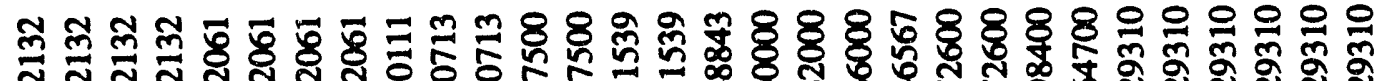

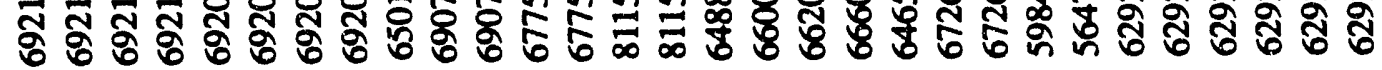

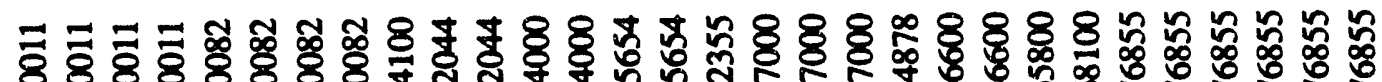

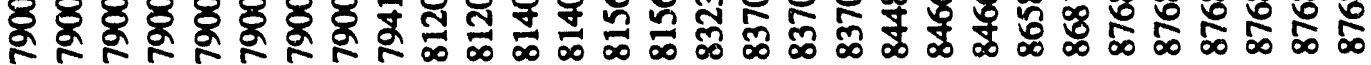

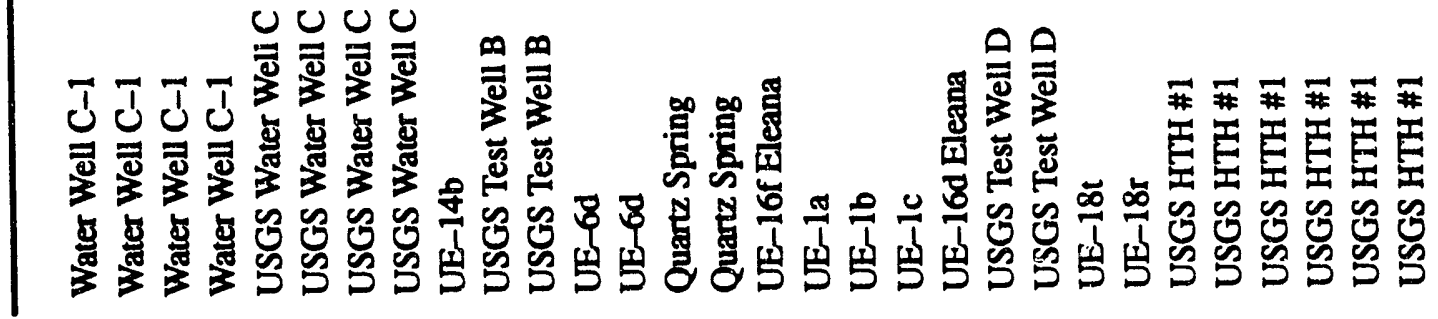




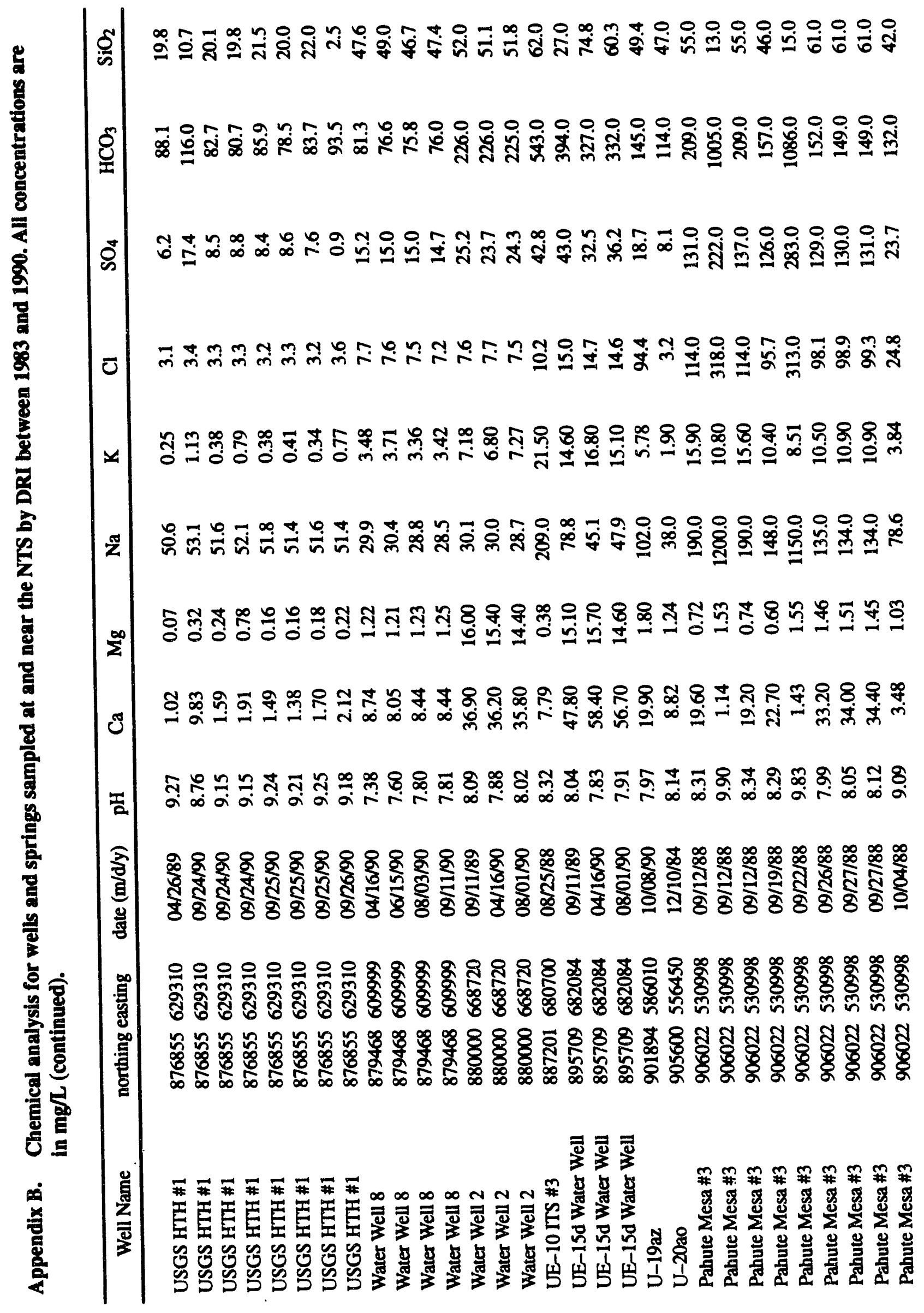




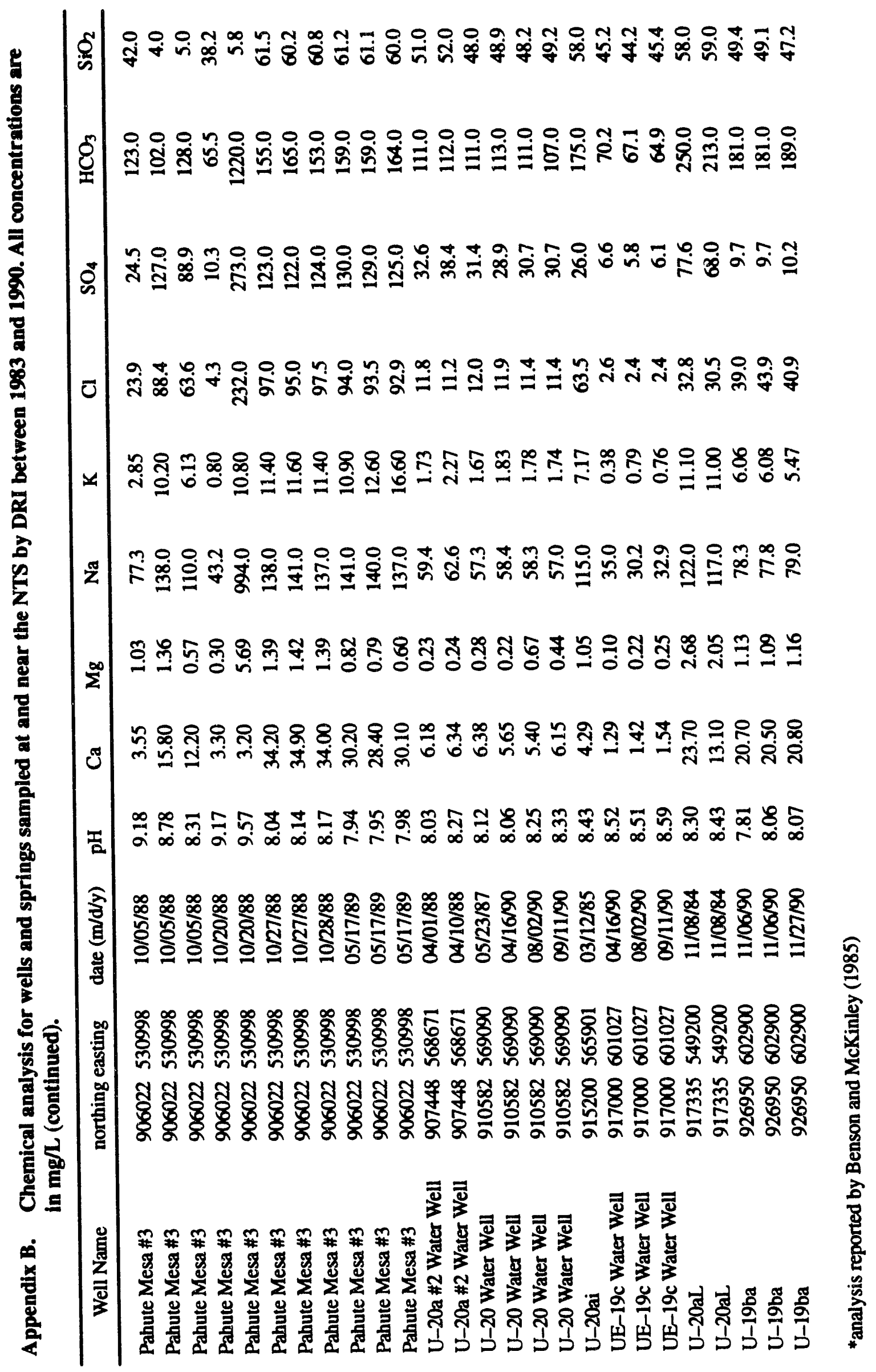




\section{APPENDIX C}

Combined chemical dataset of samples collected from 1957 to 1990, with averages calculated for locations where multiple samples have been collected. The data in this table were used to construct the maps in Figures $11,13,16$, and 17. Well names are consistent with those used in the 1991 edition of the Raytheon Services Nevada "NTS Drilling and Mining Summary." Wells are grouped according to producing formation and ordered within each group according to increasing north coordinate. 


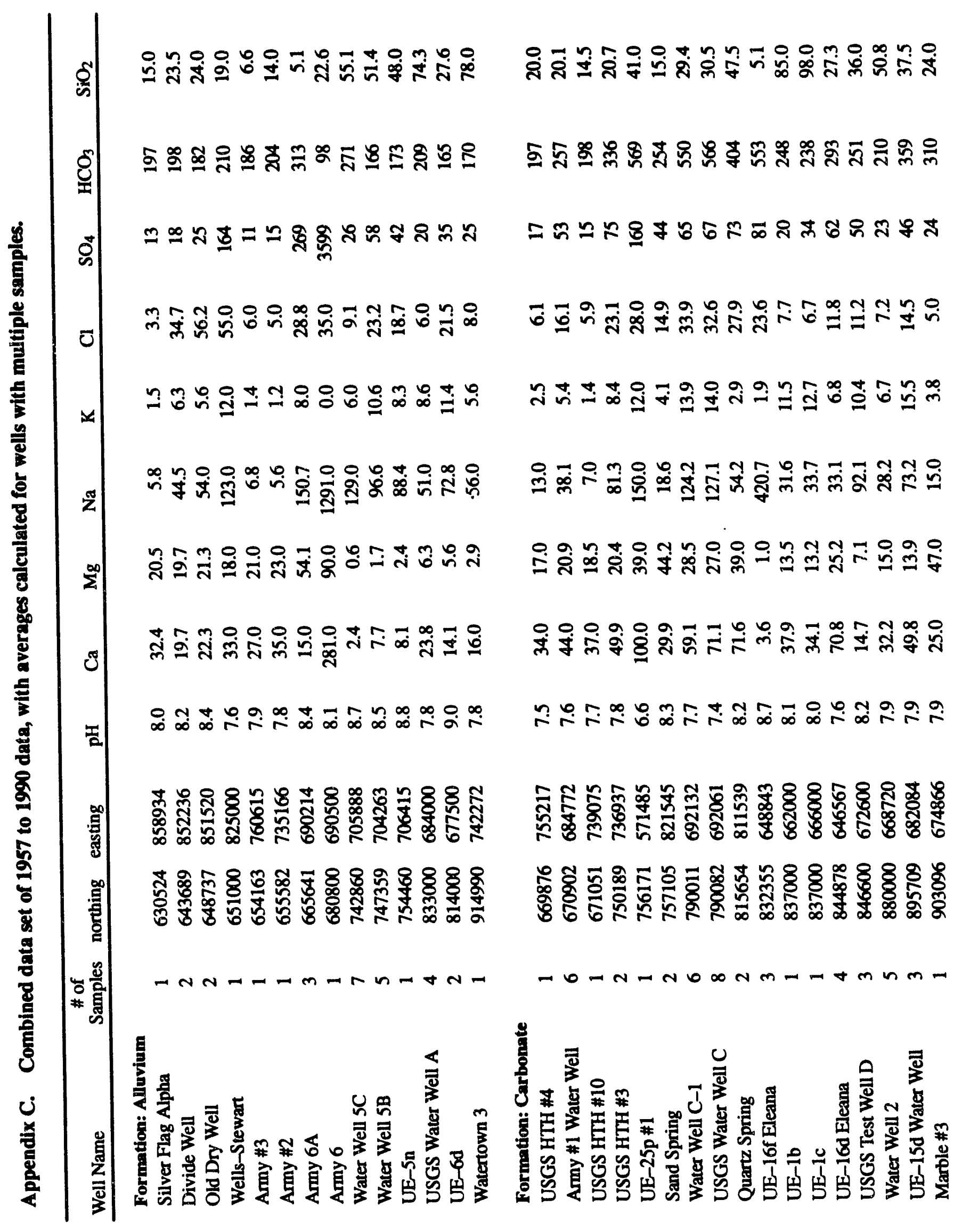




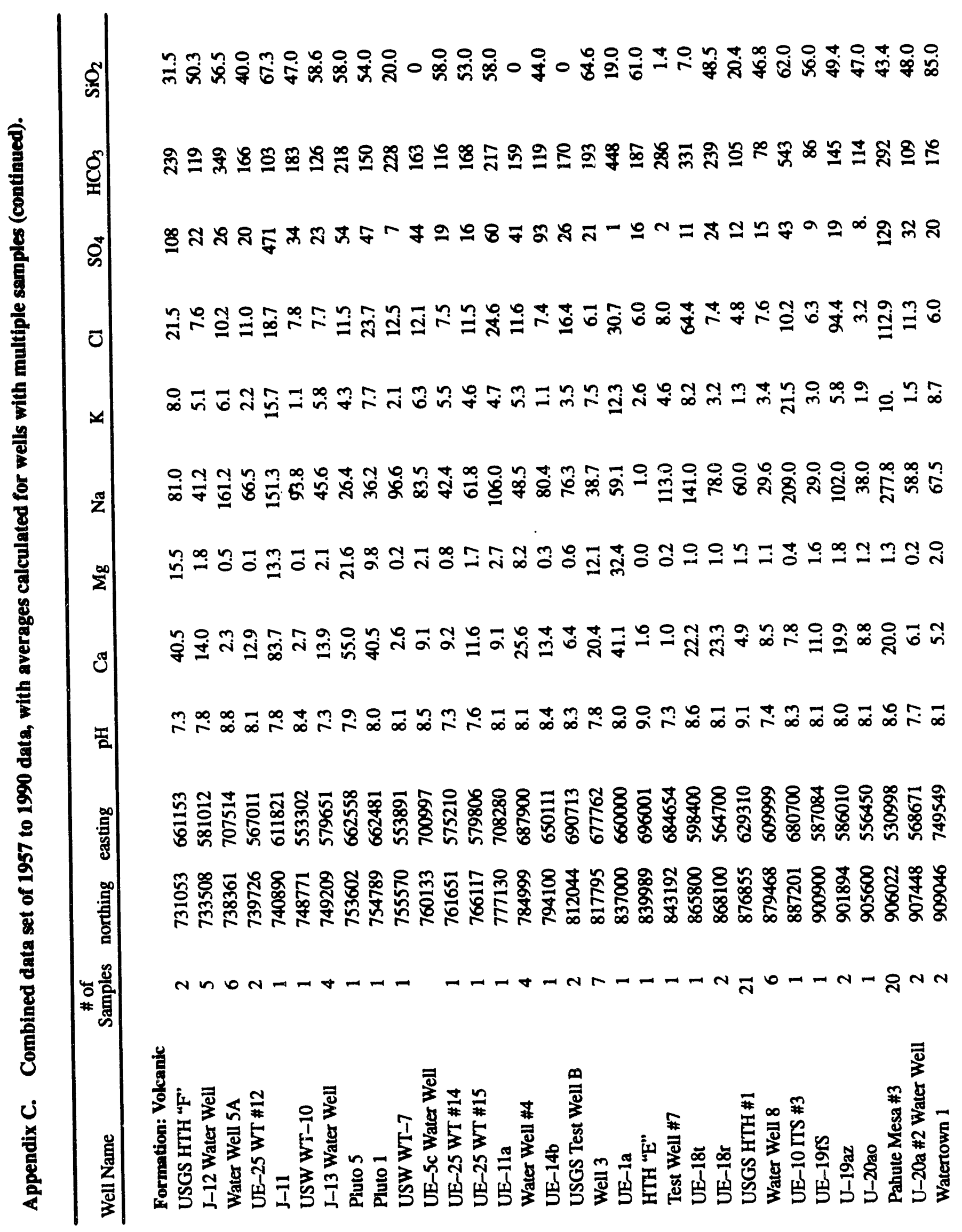




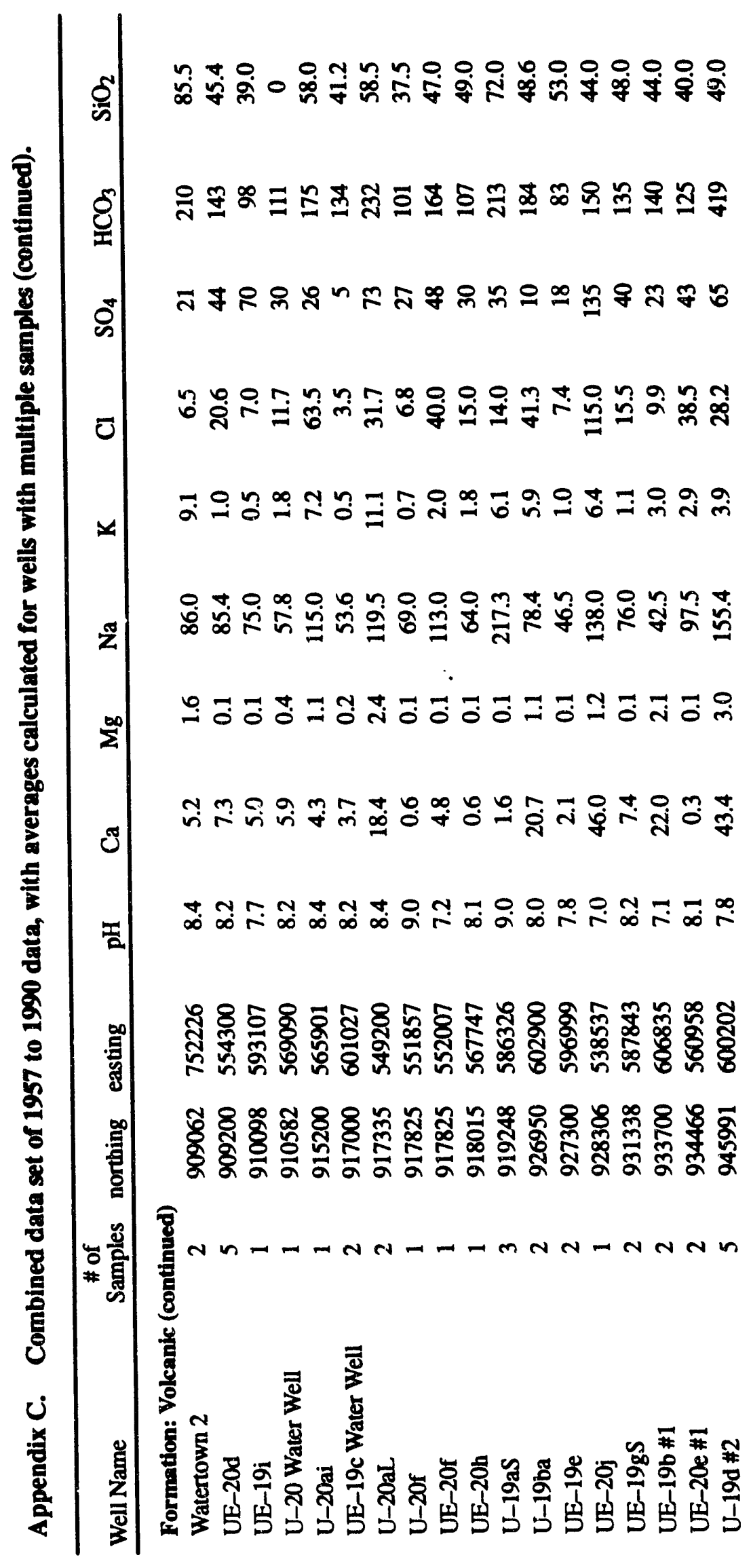




\section{DISTRIBUTION}

\section{U.S. DOE}

Gylan Allen

Test Operations Division

DOE Nevada Operations Office

U.S. Dept. of Energy

P.O. Box 98518

Las Vegas, NV 89193-8518

\section{Doug Duncan}

Hydrology Program Manager

Office of Environmental Restoration \& Waste

Management

DOE Nevada Operations Office

U.S. Dept. of Energy

P.O. Box 9851.8

Las Vegas, NV 89193-8518

Don Elle, Director

Environment Protection Division

DOE Nevada Operations Office

U.S. Dept. of Energy

P.O. Box 98518

Las Vegas, NV 89193-8518

Joseph N. Fiore, Acting Asst. Mgr.

Office of Environmental Restoration \& Waste

Mana rement

DOE Nerada Operations Office

U.S. Dept. of Energy

P.O. Box 98518

Las Vegas, NV 89193-8518

John B. Hall, Director

Technology Development \& Program

Management Division

DOE Nevada Operations Office

U.S. Dept. of Energy

P.O. Box 98518

Las Vegas, NV 89193-8518
Joseph H. Kitchen

Environmental Restoration Division

DOE Nevada Operations Office

U.S. Dept. of Energy

P.O. Box 98518

Las Vegas, NV 89193-8518

Steve Lawrence

Environmental Restoration Division

DOE Nevada Operations Office

U.S. Dept. of Energy

P.O. Box 98518

Las Vegas, NV 89193-8518

John S. Ledbetter

Contracts Division

DOE Nevada Operations Office

U.S. Dept. of Energy

P.O. Box 98518, MS 505

Las Vegas, NV 89193-8518

Steve Leedom

Test Operations Division

DOE Nevada Operations Office

U.S. Dept. of Energy

P.O. Box 98518

Las Vegas, NV 89193-8518

Steve Mellington, Director

Environmental Restoration Division

DOE Nevada Operations Office

U.S. Dept. of Energy

P.O. Box 98518

Las Vegas, NV 89193-8518

Technical Information Resource Center

DOE Nevada Operations Office

U.S. Dept. of Energy

P.O. Box 98518

Las Vegas, NV 89193-8518

Richard Pearl

Environmental Protection Division

DOE Nevada Operations Office

U.S. Dept. of Energy

P.O. Box 98518

Las Vegas, NV 89193-8518 
U.S. DOD

David Bedsun

Defense Nuclear Agency

U.S. Department of Defense

P.O. Box 98539

Las Vegas, NV 89193-8539

\section{LLNL}

Greg Nimz

Lawrence Livermore National Laboratory

P.O. Box 808, MS L233

Livermore, CA 94550

\section{LANL}

Joe Thompson

Los Alamos National Laboratory

INC-11, MS J514

P.O. Box 1663

Los Alamos, NM 87545

\section{USGS}

Virginia Glanzman

U.S. Geological Survey

Box 2506, MS 913

Denver Federal Center

Denver, CO 80225

Randy Laczniak

U.S. Geological Survey

Water Resources Division

6770 S. Paradise Rd.

Las Vegas, NV 89119

Paul Orkild

U.S. Geological Survey

Box 2506, MS 913

Denver Federal Center

Denver, CO 80225

Doug Trudeau

U.S. Geological Survey

Water Resources Division

6770 S. Paradise Rd.

Las Vegas, NV 89119

\section{DRI}

Roger Jacobson

Desert Research Institute

Water Resources Center

P.O. Box 19040

Las Vegas, NV 89132-0040

Marjory Jones

Desert Research Institute

Water Resources Center

P.O. Box 60220

Reno, NV 89506-0220

Paul Seaber

Desert Research Institute

Water Resources Center

P.O. Box 19040

Las Vegas, NV 89132-0040

\section{REECo}

Martha DeMarre

Chief, Document Research Section

Health Protection Dept.

Reynolds Electrical \& Engineering Co.

P.O. Box 98521

Las Vegas, NV 89193-8521

Brian Dozier

Reynolds Electrical \& Engineering Co.

2501 Wyandotte

Mercury, NV 89102

\section{LIBRARIES}

Interlibrary Loan

Getchell Library

University of Nevada, Reno

Archives

Getchell Library

University of Nevada, Reno

Beverly Carter

MacKay School of Mines Library

University of Nevada, Reno

Stead Library

Desert Research Institute

Reno, Nevada 
Southern Nevada Science Center Water Resources Center, Library P.O. Box 19040

Las Vegas, NV 89132-0040

Document Section, Library University of Nevada, Las Vegas 4505 Maryland Parkway

Las Vegas, NV 89154
Water Resources Research Archives

University of California

Room 40, North Gate Hall

Berkeley, CA 94720

IT

Rick Waddell

Geotrans

c/o IT

4330 Valley View

Suite 112

MS-439

Las Vegas, NV 89103

Joe Yeasted

International Technology Corp.

Southem Nevada Science Center

P.O. Box 19040

Las Vegas, NV 89132-0040 

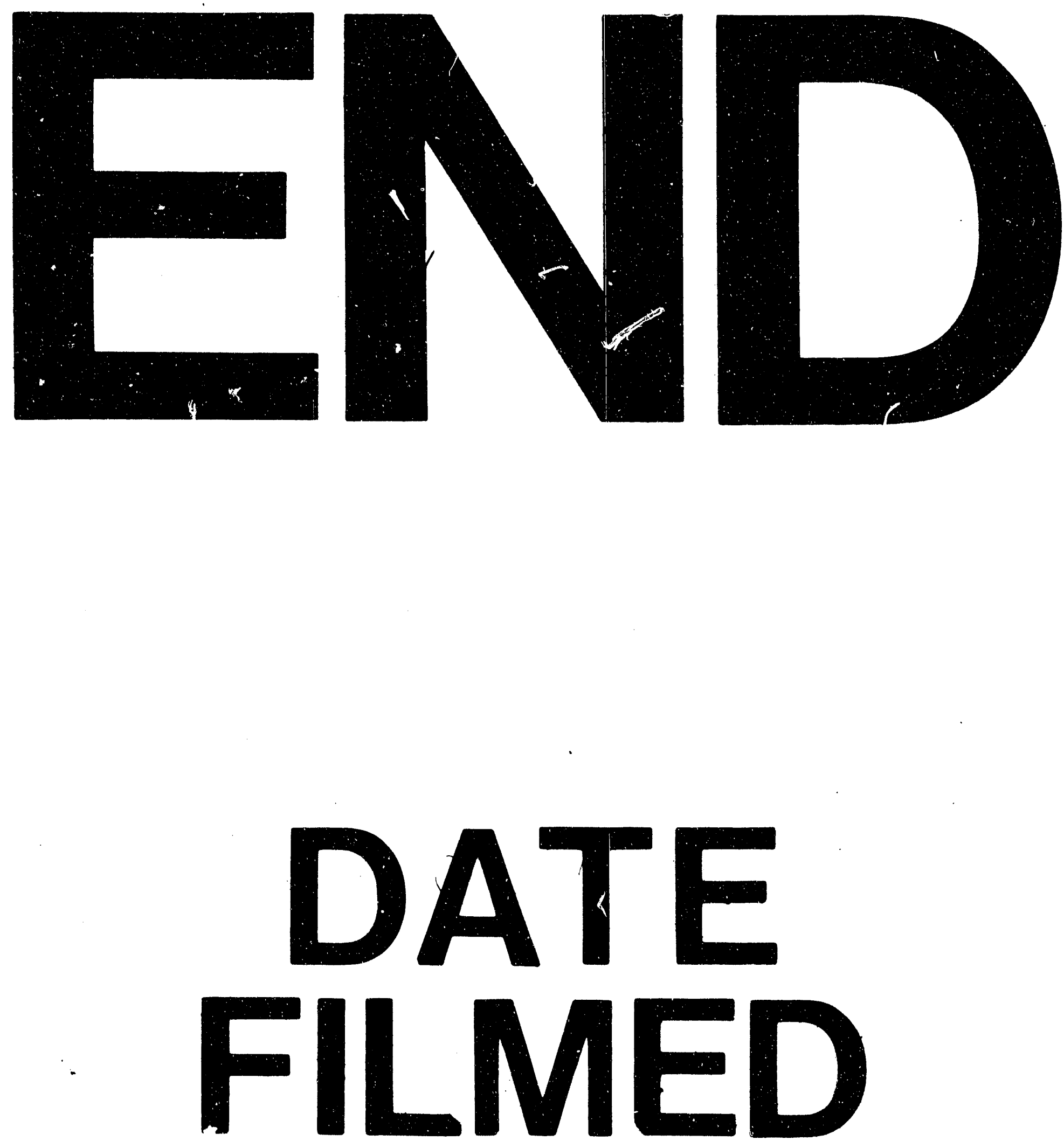

i

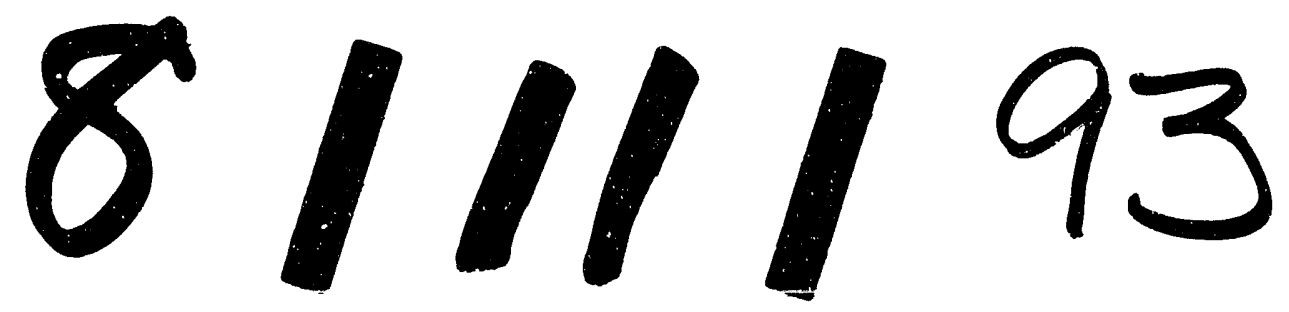


